4 nordon 



\section{Developing the co-operation between the established less formal Nordic approaches to eco-management and eco- certification systems}

Part 1

Mira Jarkko, City of Helsinki Environment Centre

Ann-Christine Eriksson, Eco Profile company

TemaNord 2009:558 
Developing the co-operation between the established less formal Nordic approaches to ecomanagement and eco-certification systems

Part 1

TemaNord 2009:558

(C) Nordic Council of Ministers, Copenhagen 2009

ISBN 978-92-893-1901-0

Copies: 0

Printed on environmentally friendly paper

This publication can be ordered on www.norden.org/order. Other Nordic publications are available at www.norden.org/publications

Printed in Denmark

Nordic Council of Ministers

Store Strandstræde 18

DK-1255 Copenhagen K

Phone (+45) 33960200

Fax (+45) 33960202

www.norden.org

\section{Nordic Council}

Store Strandstræde 18

DK-1255 Copenhagen K

Phone (+45) 33960400

Fax (+45) 33111870

\section{Nordic co-operation}

Nordic cooperation is one of the world's most extensive forms of regional collaboration, involving Denmark, Finland, Iceland, Norway, Sweden, and three autonomous areas: the Faroe Islands, Greenland, and Åland.

Nordic cooperation has firm traditions in politics, the economy, and culture. It plays an important rol in European and international collaboration, and aims at creating a strong Nordic community in a strong Europe.

Nordic cooperation seeks to safeguard Nordic and regional interests and principles in the global community. Common Nordic values help the region solidify its position as one of the world's most innovative and competitive. 


\section{Content}

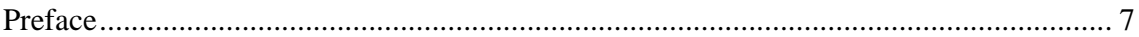

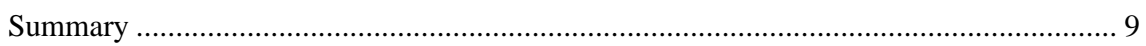

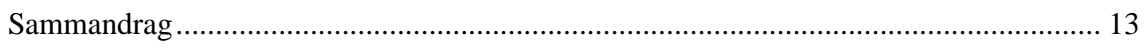

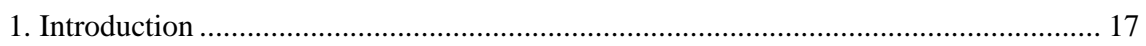

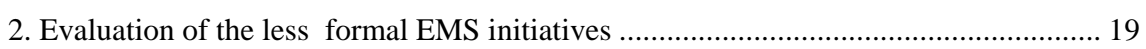

2.1. Evaluation of the five Nordic initiatives........................................................... 19

2.2. The 4Steps methodology - comparison of the criteria and tools

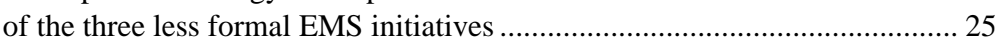

3. The common platform for the Nordic less formal EMSs opens up for further

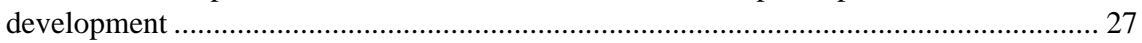

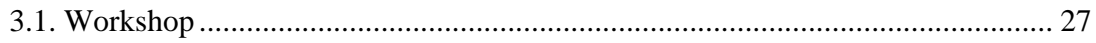

3.2. Frontrunner enterprises - case Steen \& Strøm ................................................ 29

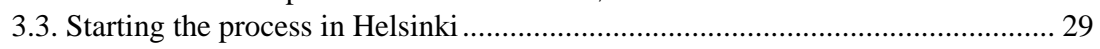

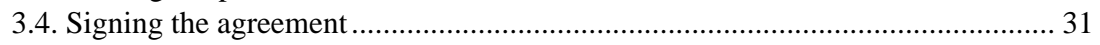

4. Looking back on the project - evaluation and conclusions.......................................... 33

4.1. The main success factor: Nordic cooperation....................................................... 33

4.2. Working methods: something special and some room for development ............. 33

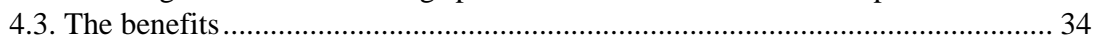

4.4. The role of frontrunner businesses .................................................................. 34

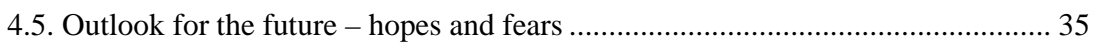

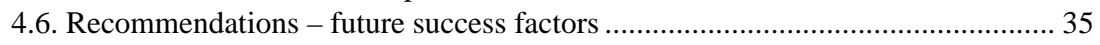

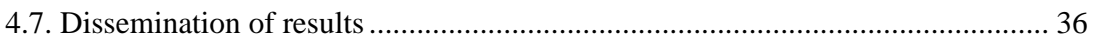

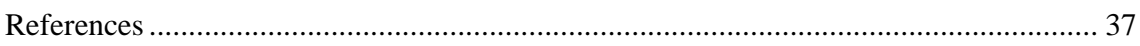

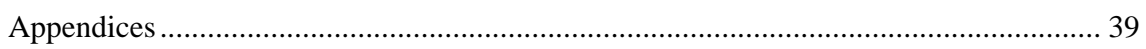





\section{Preface}

There are several successful less formal approaches to eco-management and eco-certification systems for small and medium enterprises (SMEs) in the Nordic countries (for example Eco-Lighthouse Norway, Environment Diploma Sweden and Green Network/Key2Green Denmark) that promote successful co-operation between municipalities and businesses. It was found necessary to assess these different Nordic certification systems and search for ways with which to coordinate them. The efforts have resulted in a common platform, which can form the basis for a shared development direction in the future.

Nordic co-operation between these approaches and the coordination effort were discussed at a workshop held in Helsinki in March 2008. An agreement on co-operation was drafted in Gothenburg in June and a common platform will be established at the Odense Conference in September.

This report summarises the discussions held between involved Nordic actors and the results of the coordination process. The results of the evaluation of the Nordic less formal EMS initiatives and the developed 4Steps methodology are presented in the second chapter. The third chapter deals with the process of developing a common platform for Nordic less formal approaches, including the workshop which was held in Helsinki on 12-13 March 2008. Chapter four consists of an evaluation of the project and of suggestions for the future.

The project is continuing under the lead of the City of Goteborg in Sweden. 



\section{Summary}

Customers and consumers voice their environmental concerns more and more frequently. To meet their requirements, suppliers can implement an environmental management system based on either the ISO 14001 or EMAS standards, which require a lot of resources (both time and money), but are well known - or they can opt for a less formal EMS, which is not as bureaucratic and instead focuses on concrete environmental work, but is internationally less well known. Small and medium enterprises tend to favour the less formal systems because of their down-to-earth approach and lower costs.

Several successful less formal approaches to eco-management and eco-certification systems that promote the co-operation between municipalities and businesses exist for SMEs in the Nordic countries (for example Eco-Lighthouse Norway, Environment Diploma Sweden and Green Network/ Key2Green Denmark). In addition to environmentallybeneficial actions, implementation of these models has fostered valuable know-how and competence in the Nordic region. In order to get more firms involved and to give these businesses even better value from using a less formal EMS, there is a need to search for ways with which to coordinate these locally adopted systems. This is best done by examining experiences of existing systems and by following good experiences and learning from the less successful initiatives. ${ }^{1}$

It is necessary for the Nordic region to show itself as a good example in the coordination of future development directions for the less formal approaches to eco-management. Common platforms will strengthen the prestige of Nordic environmental management systems in Europe and improve the competitiveness of the Nordic region. In the field of business and environmental protection, it would also promote awareness of the importance that Nordic cultures assign to green values and trustworthiness.

The City of Helsinki has been the coordinator of the Nordic project. It has not yet set up a system for developing the environmental performance of SMEs, but has initiated an effort in the Helsinki Metropolitan area that follows the good experiences of Nordic initiatives and the coordination process.

${ }^{1}$ EU have been adviced to facilitate so called "less formal” approaches to EMS for small and medium sized enterprises: EU, "Best Project"; http://europa.eu.int/comm/ enterprise/environment/events/sme_conference 


\section{Evaluation of five established less formal EMS initiatives}

In order to coordinate the future direction for the development of the Nordic models, it is important to utilise existing experiences and evaluate established less formal EMS initiatives. All of the five systems included in this survey meet the central requirements of the ISO 14001 and EMAS standards, but they are less bureaucratic and not as expensive to implement. This makes them easier to understand and more user-friendly. The less formal EMSs also focus more on performance demands and results rather than process demands like the formal EMSs. These are the reasons why there is a growing demand for less formal EMS initiatives.

Another significant difference in relation to the ISO 14001 and EMAS standards is the role municipal authorities play. Municipal involvement is very strong in some systems. This strengthens the dialogue between municipalities and companies.

The five assessed systems have many features in common. This is a significant issue from the point of view of the development of the common platform and the future co-operation process.

\section{Business challenges for Nordic co-operation: Case Steen \& Ström}

Although Nordic co-operation is in many ways useful to cities, the coordination of systems accross the Nordic countries benefits SMEs the most. At the moment, if a company utilises a local less formal environment system it gains no direct benefits from this beyond the borders of its home country. Steen \& Ström, a Nordic shopping-centre proprietor, wanted to utilise local systems in Norway, Sweden and Denmark, but considered it desirable for the systems of different countries to be as alike as possible. Steen \& Ström itself is a big company, but its 54 shopping centres are SMEs and hundreds of small and medium enterprises operate at each shopping centre. In total, this means that we can influence thousands of shops and restaurants through one large central operator.

This presented a very concrete challenge for Nordic co-operation. Over the course of the Nordic E-COOP project, the firm has initiated environmental efforts in all three countries. The different local less formal EMS initiatives have engaged in dialogue on the development of the common platform of practices and requirements to great effect. The practical viewpoints and requirements the company has introduced to the debate have been helpful because they point out tangible benefits from coordination and provide a schedule for the co-operation effort.

Steen \& Ström also took part in the Helsinki workshop, where it described the achieved results to the other 30 or so participants who represented nine different less formal EMS systems from all five Nordic coun- 
tries. The idea of a common Nordic organisation between the less formal EMS initiatives was presented at the Nordic E-COOP for SMEs workshop.

\section{The 4steps methodology: Initiative, Plan, Act \& Certify}

The 4steps methodology was developed initially together with Steen \& Ström to help the implementation of the three different initiatives in three countries. The 4steps methodology forms the basis for future cooperation and it is the first practical guide for businesses that wish to use a local/national less formal EMS in more than one Nordic country.

\section{A common platform for a Nordic less formal EMS opens up for further development}

Coordinating the development of a common platform is an extensive process and it requires plenty of time. So far, Nordic co-operation has produced concrete results, such as the agreement on the coordination of the future development directions (Appendix 1), the 4Steps methodology to help involved businesses as well as Helsinki's development project.

The working method with the target group (frontrunner enterprises) has provided a lot of important information about the practical environmental needs of businesses. However, most of the work to establish the common platform has been done by those who run the systems.

For the systems themselves, the Nordic co-operation has been tremendously important. The exchange of experiences has fostered their development and enabled them to pool limited resources and develop shared tools and methods together. The coordination of the efforts and the further development of a common direction for future development are still in an early stage and its success will require the allocation of more time and resources. 



\section{Sammandrag}

Det blir allt allmännare att kunder och konsumenter visar intresse för miljöfrågor. För att tillmötesgå sina kunder kan företag gå in för ett miljöstyrningssystem. En möjlighet är att ta till den internationella standarden ISO 14001 eller den europeiska EMAS, som båda kräver stora resurser i tid och pengar men som är väl kända. Ett mindre tungrott alternativ är att ta till ett av miljöstyrningssystemen med lägre formkrav; dessa är i högre grad inriktade på konkreta miljöinsatser och en enklare byråkrati, låt vara att dessa inte har blivit lika kända på det internationella planet. Små och medelstora företag föredrar att satsa på system med mindre formkrav, tack vare att dessa är mera jordnära och framför allt billigare.

Det förekommer i de nordiska länderna flera system för miljöstyrning och miljöcertifiering med lägre ställda formkrav, system som främjar samverkan mellan kommuner och företag, exempelvis Miljøfyrtårnet i Norge, MiljöDIPLOM i Sverige eller Green Network/ Key2Green i Danmark. Modeller av det här slaget har inte bara lett till miljöskonande åtgärder utan de har också tagit fram värdefulla kunskaper och tillfört de nordiska länderna ökad kompetens. För att flera företag skall förmås att gå med och engagera sig i system av det här slaget och för att dessa företag skall kunna dra bättre nytta av de mindre formkrävande miljöstyrningssystemen, behöver det tas fram nya sätt att koordinera dessa lokalt uppkomna system. Det kan bäst ske genom studier av de förefintliga systemen och identifiering av den bästa praxisen i dem, men också så att lärdomar dras av de initiativ som visat sig vara mindre lyckade. ${ }^{2}$

En samordning av de nordiska miljöstyrningssystemen bör öka dessa systems prestige på Europanivå och höjer sannolikt Nordens konkurrenskraft. Det är väsentligt att Norden förs fram som en förebild i den framtida koordinationen av riktlinjerna för utvecklingen av mindre formkrävande miljöstyrningssystem. Likaså bör en gemensam plattform för miljösystemen i affärs- och miljövårdssammanhang betona vilken stor betydelse gröna värderingar och tillförlitlighet tillmäts i de nordiska kulturerna.

Helsingfors stad har skött uppdraget som koordinator för detta nordiska projekt. Hittills har staden inte skapat något system för utvecklingen av sm-företagens miljöeffektivitet, men staden har för Helsingforsregionen gått igång med satsningar som bygger på erfarenheterna av de nordiska initiativen och koordinationsprocessen.

\footnotetext{
${ }^{2}$ EU har uppmanats att underlätta så kallade mindre formella miljöstyrningsmetoder för små och medelstora företag: EU, "Best Project”; http://europa.eu.int/comm/enterprise/ environment/events/sme_conference
} 


\section{Fem av de etablerade miljöstyrningssystemen med lägre formkrav utvärderas}

Inför koordinationen av utvecklingslinjerna för de nordiska modellerna är det väsentligt att de förefintliga erfarenheterna utnyttjas och att de olika systemen för miljöstyrningssystem med lägre formkrav utvärderas. Samtliga system som ingår i denna översikt uppfyller de centrala kraven i standarderna ISO 14001 och EMAS, men de har enklare byråkrati och de kostar mindre att tillämpa. Det gör att de är överskådligare och användarvänligare. Miljösystemen med lägre formkrav är också mer inriktade på effektivitets- och resultatkrav, snarare än på de processkrav som kännetecknar systemen med högre formkrav. Det är därför som efterfrågan på miljöstyrningssystem med lindrigare formkrav tilltar.

En annan väsentlig skillnad jämfört med standarderna ISO 14001 och EMAS är de roller som de kommunala instanserna spelar. I vissa av systemen med lägre formkrav är kommunernas medverkan starkt betonad. Detta är ägnat att stärka dialogen mellan kommunerna och företagen.

De fem systemen som är föremål för utvärderingarna uppvisar många gemensamma drag. Detta är viktigt med tanke på utvecklingen av en gemensam plattform för systemen och inför det framtida samarbetet.

\section{Utmaningar för nordiskt affärssamarbete - exemplet Steen \& Strøm}

Även om det nordiska samarbetet på många sätt är till fördel för städer och kommuner, så är det sm-företagen som drar den största nyttan av miljösystemens koordination på nordisk nivå. Företag som håller sig till något av de nationella miljöstyrningssystemen med lägre formkrav har för närvarande inte någon direkt nytta av detta utanför det egna landets gränser. Steen \& Strøm, ett företag som äger nordiska köpcentra, ville använda sig av de lokala miljösystemen i Norge, Sverige och Danmark, men ansåg det vara önskvärt att systemen i de olika länderna skulle vara så lika varandra som bara möjligt. Steen \& Strøm är ett stort företag, men dess 54 köpcentra är sm-företag, och i dessa ingår hundratals små och medelstora företag. Sammanfattningsvis betyder det att vi genom denna stora centraloperatör kan inverka på tusentals affärer och restauranger.

Situationen ställde mycket konkreta krav på det nordiska samarbetet. Under det nordiska ekosamarbetsprojektets gång har Steen \& Strøm inlett miljöstyrningsåtgärder i de tre länderna där företagen verkar. De olika ländernas miljöstyrningssystem med lägre formkrav har inlett diskussioner om framtagningen av en gemensam plattform för tillvägagångssätten och kraven, och goda resultat har uppnåtts. De praktiska synpunkter och krav som framställts från företagets sida har varit till god nytta, eftersom 
de för fram de påtagliga fördelarna med koordinationen och bildar en agenda för samarbetsåtgärderna.

Steen \& Strøm var också med i "workshoppen” i Helsingfors, och bidrog där med en beskrivning av de uppnådda resultaten inför de övriga ca 30 deltagarna, som företrädde nio olika miljöstyrningssystem med lägre formkrav, från de fem nordiska länderna. Tanken på en gemensam nordisk organisation som skall samla miljöstyrningssystemen med sänkta formkrav presenterades under workshoppen för nordiskt samarbete för sm-företag.

\section{Fyrastegsmetoden: Initiativ, planering, åtgärder \& certifiering}

Fyrastegsmetoden utvecklades till en början i samråd med Steen \& Strøm i syfte att samordna de tre olika systemen i de tre länderna. Fyrastegmetoden utgör grunden för det kommande samarbetet och den är den första praktiska handledningen för företag som vill utnyttja lokala eller nationella miljöstyrningssystem i mer än ett nordiskt land.

\section{Den gemensamma plattformen för de nordiska miljöstyrningssystemen med sänkta formkrav öppnas för vidareutveckling}

En koordinerad utveckling av den gemensamma plattformen är en omfattande och tidskrävande process. Hittills har det nordiska samarbetet producerat konkreta resultat, bl.a. överenskommelsen om koordinerade riktlinjer för den framtida utvecklingen (bilaga 1), fyrastegsmetoden till hjälp för företagen samt utvecklingsprojektet i Helsingfors.

Arbetsmetoden som bygger på en målgrupp (föregångarföretag) har lett till mängder av viktig information om företagens praktiska behov i miljöfrågor. Det är dock de instanser som styr systemen som gjort de största insatserna för skapandet av den gemensamma plattformen.

För själva systemen har det nordiska samarbetet varit av enorm betydelse. Utbytet av erfarenheter har gett upphov till utvecklingen och skapar förutsättningar för de medverkande att slå samman sina begränsade resurser och att tillsammans utveckla hjälpmedel och metoder. Koordinationen av satsningarna och vidareutvecklingen av de gemensamma riktlinjerna befinner sig än så länge på ett tidigt stadium; för uppnående av de eftersträvade resultaten krävs mer tid och större resurser. 



\section{Introduction}

\subsection{Backround of the project}

Several approaches and certification systems are in place in the Nordic countries with the aim of improving the environmental performance of SMEs. Common for the approaches included in this project is the cooperation between municipalities and businesses. There has already been some co-operation between these systems and cities, but many differences in the manner with which the systems are constructed and what kinds of certification criteria they utilise can still be identified.

The City of Helsinki has been the coordinator of this Nordic project. The City of Helsinki has not yet set up a system for developing the environmental performance of SMEs, but has initiated an effort in the Helsinki Metropolitan area that follows the good experiences of Nordic initiatives and the coordination process. According to Nordic experiences, co-operation between local municipalities and businesses forms a very important part of the development process. This has also been seen as a major success factor in the Eco-Lighthouse, Environment Diploma and Green Network/ Key2Green schemes.

The initiators of the project are the City of Helsinki Environment Centre, the Helsinki Business Development Unit, the Wholesalers Business Association, the Uusimaa Regional Environment Centre, the City of Göteborg, the Finnish Environment Administration, the City of Järfälla, the City of Oslo, the City of Kristiansand, the Eco-lighthouse Foundation, the Green Network of Denmark and the national organisation Swedish Environment Base.

The project was lauched on 1 November 2007 and finished at the end of June 2008.

\subsection{Objectives of the project}

The overall objective of the project was to enhance the environmental performance and competitiveness of SMEs in Nordic countries. Other objectives were:

- Developing pan-Nordic co-operation by assessing the established "less formal" environmental management systems for SMEs

- Identifying a common platform for future development. 
- To find ways of strengthening the co-operation between the local economy and different municipal sectors

- To develop existing systems together in order to achieve the best results in improving both the state of the environment and the competitiveness of the Nordic region. 


\section{Evaluation of the less formal EMS initiatives}

\subsection{Evaluation of the five Nordic initiatives}

During the latest decades, successful certification systems have been created in special regions in the Nordic countries. In addition to environmentally-beneficial actions, implementation of these models has fostered valuable know-how and competence in the Nordic region. In order to develop and coordinate the Nordic models it is important to take advantage of existing experience.

The aim of this study is to assess five less formal EMS frameworks with focus on differences in the systems and the roles of involved interest groups. The subjects of the study are:

\begin{tabular}{lll}
\hline EMS & Country & Representative \\
\hline Eco-lighthouse & Norway & $\begin{array}{l}\text { Eco-Lighthouse, Kristiansand, } \\
\text { Morten Leuch Elieson }\end{array}$ \\
Key2Green & Denmark & Green Network, Vejle, Ole Dall \\
Environment Diploma & Sweden & $\begin{array}{l}\text { City of Göteborg, Göteborg, } \\
\text { Peer-Erik Carlsson }\end{array}$ \\
EcoStart & Finland & $\begin{array}{l}\text { Employment and Economic Development Centre for } \\
\text { South Savo, Timo Lehtinen }\end{array}$ \\
EMS light Nordic & Åland, Island, & $\begin{array}{l}\text { PlanMiljö, Denmark, Tomas Sander Poulsen, and } \\
\text { Fann-Christine Erikson, the local consultant in } \\
\text { Alland }\end{array}$ \\
\hline
\end{tabular}

The EMS initiatives are assessed regarding

- similarities and differences regarding the demands of the systems

- benefits to the enterprises and to the municipalities

- amount of system users

- requirements on reporting, regular follow-up

- costs for involved partners, potential financial support

- responsibilities regarding marketing of the systems

- need of external environmental training in the enterprises

- publications regarding experience of the systems

- communication between interest groups in the network

- the role of the municipalities, need for co-operation

- practical examples 
The assessment is based on features of and experience from the five environmental management systems and it provides background information regarding the developing the common platform of the systems and strengthening of the co-operation between the enterprises and local authorities.

\subsubsection{Amount of users}

\begin{tabular}{lrr}
\hline & Established & Users 2007 \\
\hline Eco-Lighthouse & 1996 & 1120 \\
Green Network & 1994 & 285 \\
Environment Diploma & 1995 & $350^{\star}$ \\
EcoStart & 2006 & 48 \\
EMS Light Nordic & 2007 & 16 \\
\hline
\end{tabular}

* in Göteborg and the Göteborg Region, 13 municipalities

\subsubsection{Funding}

\section{Eco-Lighthouse}

Eco-lighthouse is self-financed since 2005.

The companies pay a connection fee of $1800-10800$ NOK, and after certification an annual service fee of $800-10000$ NOK, depending on the size of the company. The price of the certificate is $500 \mathrm{NOK}+300$ NOK service fee. The consultant and the company negotiate for the consulting fee. In some municipalities the company has possibility to get financial support from the municipality for the environmental analyses that the company carries out together with the consultant.

\section{Green Network}

Green Network is one of the organisations acting under Key2Green, which is a self-financed umbrella organisation for seven regional networks. Companies, so called V-members, pay an annual membership fee of 3000 DKK (< 150 employees) or 4000 DKK ( $>150$ employees) and receive free assistance from the municipalities in organising their EMS. Green network is a regional network including six municipalities, Omembers, which support the project with 6,80 DKK per inhabitant. Interested organisations and companies, I-members, pay 2500 DKK per year.

Environment Diploma

Environment Diploma is self-financed. All income comes from the involved companies. The registration fee for Environment Diploma is 4000 SEK which is charged when a declaration regarding the environmental issues has been accepted by the municipality. After an initial meeting the enterprise receives an offer of the remaining work. The minimum fee is 8 000 SEK including the registration fee. The average fee is 12000 SEK. 
The fee depends on size, activities and the scope of the authorities' work with the enterprise. Companies pay in average 7500 SEK for recertification. The cost for Basic Environment Training is added to the sum for the first diploma. Most of the courses are held by consultants.

To join the network consisting of interested municipalities the municipality has to pay 3500 SEK/a. The network consists of 29 municipalities, half of them in the Region of Göteborg.

\section{EcoStart}

EcoStart is a subsidized environmental consulting service for SMEs in Finland. It belongs to a group of consulting service products of Ministry of Employment and the Economy. The provincial federation of South Savo has financed the development of EcoStart. Since 2006 each involved T\&E Centre subsidises the implementation of EcoStart in the companies with maximum $70 \%$.

The participating companies pay 100-300 € per workshop for consulting service depending on the size of the company. At minimum four consulting days are needed. The audit day is $50 €$ more expensive than the consulting days.

\section{EMS Light Nordic}

The project is subsidised by the Nordic Council and the local environmental authorities in Iceland, Faeroe Islands and Åland. The development of the model is covered by the support from the Nordic Council. The local environmental authorities subsidise the project with 100000 DKK. The companies pay a participation fee of 10000 DKK each, which is aimed at partly cover the consulting fees.

\subsubsection{Similarities and differences in the demands of the systems}

All five subjects of this survey have many features in common. They correspond to the central criteria of ISO 14001 and EMAS, but are less bureaucratic and less expensive. All systems are easy to develop towards ISO 14001 and EMAS, if later on needed. The main difference to ISO 14001 and EMAS is that the less formal EMSs are minimizing requirements on documentation and document managing. At the same time, they are more focused on performance and the results rather than the process. This makes the EMSs easy to understand and easy to use. That is also the reason why there is a growing demand of less formal EMS initiatives.

The main part of the systems is quite similar, although in some cases different terms are used for same issues. The most important similarities, which are the common platform and understanding that was established between the three initiatives (Eco-Lighthouse Norway, Environment Diploma Sweden and Green Network/ Key2Green Denmark) during the project, are listed below: 
They are focusing on concrete measurable environmental improvements, not on high requirements on documentation

The environmental program is the main issue, around which the environmental work is built up

In all five models the environmental program or statement requires:

1. Environmental analysis regarding environmental aspects and impacts

2. Targets

3. Action plan

4. Knowledge and fulfilment of legal requirements

5. Defined responsibilities, environmental representative

6. Regular environmental training

7. Checklists

8. Environmental report

The benefits to the companies of having a less formal EMS seem to be the same in all five EMS models:

- The companies appreciate a simple EMS, which is focusing on measurable cost-effective improvements and is easy to understand and to use

- All models offer competitive edge

- All models provide a good communication channel to interest groups

- All models give the enterprises a good start, if ISO 14001 or EMAS implementations are needed later on

- All models strengthen the company image

- All models motivate the personnel and strengthen the team spirit

\subsubsection{Main results}

The five assessed systems have many features in common. All five models are less formal than ISO 14001 and EMAS. The most essential parts of an effective structural environmental work are included in all systems. The systems are focusing on concrete environmental improvements, not on detailed documentation routines. The requirement on certification and regular re-certification motivates the companies to keep up the process regarding continuous improvement. In the case EMS light Nordic, that does not require certification; the company must be motivated to continue the environmental work on its own initiative after the project period. It is extremely important that the results of the environmental work are visible and profitable.

A significant difference in relation to ISO 14001 and EMAS is also the role of the municipalities. The municipal involvement is very strong in some systems like Environment Diploma and Green Network, where no external consultants are used. The municipalities' own experts are acting 
advisors to the companies. This strengthens the dialogue between the municipalities and the companies. Regarding Eco-Lighthouse and EcoStart consultants are educated to assist the companies. For the EcoStart project, consultants are also educated to carry out the certification audit, while EcoLighthouse uses municipal representatives for the certification process. Regarding EMS Light Nordic the environmental authorities choose the consultant.

Although all the models are much alike, some features could be characterized as strengths for each system compared to the other assessed systems. These features are listed below:

\section{Eco-Lighthouse}

A numerous amount of users, well known in Norway own website www.miljofyrtarn.no the certificate is geographically neutral so that all municipalities can use it the action plan is included in the company's budget plan strengthens the co-operation between companies, municipalities and other interest groups

\section{Green Network}

- included in the national umbrella Key2Green

- own website www.greennetwork.dk and www.key2green.dk

- the dialogue between local authorities and companies is central and a very strong element in the concept

- the flag and the diploma gives visibility

\section{Environment Diploma}

- included in the national umbrella Swedish Environmental Base

- own website www.miljodiplom.se

- the strong local consolidation strengthens the co-operation between companies and the local municipality

- easy to work independently with the pedagogical model

\section{EcoStart}

- strong focus on cost-saving actions

- includes actions for slowing climate change

- the companies' time resources are observed

- low costs for companies

\section{EMS Light Nordic}

- own website www.ems-light.org

- the Excel-based follow-up system allows a continuous graphical follow-up of both consumptions and costs

- easy to visualize results from made actions 
All systems have in common that they are clear and relatively simple. They are suitable especially for SMEs with limited resources but a genuine will to work systematically with environmental matters. With the EMS, the ecoefficiency will increase and the company image will improve.

\subsubsection{Conclusions}

Environmental requirements from customers and consumers are growing constantly. To meet these requirements the suppliers can implement an EMS according to either ISO 14001 or EMAS, which require many resources regarding time and money but are well known, or a less formal EMS, which is less bureaucratic focusing on the concrete environmental work, but less known internationally. For SMEs, the less formal systems are popular because of their down-to-earth touch and lower costs. Anyhow, companies cannot fully benefit from the less formal EMS in their marketing, because the EMS alternatives are mostly known locally/regionally. On the international level, it is not easy for the customer to know what the different EMS alternatives present compared to each other.

Currently established less formal EMSs are known in regions where the municipalities are supporting the project. In Norway, the ECOLighthouse foundation is working nationally. In Sweden and in Denmark national umbrellas have been established in order to collect less formal EMSs, which fulfil certain criteria, under the same roof. This helps the EMSs to become more known and to expand. Still the national umbrellas are not known outside the nation borders. The next step in the development of Nordic EMSs could be to develop a Nordic umbrella. This would give the Nordic EMSs credibility and make them known in all Nordic Countries.

SMEs expect clear measurable improvements and they should be costeffective. In addition to the more eco-effective business, the companies also expect that the EMS offer competitive advantage. For SMEs it is important that the implementation of the system can be carried out with relatively low costs and that the project is not too time-consuming. The personnel at SMEs are mainly bound to day-to-day tasks and resources for development work are extremely small. Concrete results are a necessity to keep management and personnel motivated and to make the environmental work successful. In addition, the requirements on a regular recertification are important to motivate the companies to go on with the environmental improvements after certification.

A benefit with all five assessed systems is that they are developed to suit all kinds of SMEs. The number of employees can vary from a few to a couple of hundred and the environmental impact varies depending on the business sector. Even a less formal EMS can seem to be too bureaucratic and too expensive to micro businesses if the EMS cannot meet their specific needs. 
The close co-operation between municipalities and companies strengthens the relation between the private sector and government officials. It is important that the companies fully understand that besides the authority role government officials also have a role as advisor to different actors in the society, among others SMEs. A less formal EMS supported by the municipality is a good example of a valuable co-operation where the municipality acts as advisor. (See the whole evaluation report in Appendix 2.)

\subsection{The 4Steps methodology - comparison of the criteria and tools of the three less formal EMS initiatives}

Initially, the 4steps methodology was developed together with Steen \& Ström to assist in the implementation of the three different initiatives in three countries (shopping centres). According to the methodology, activities shall be performed and results achieved though four steps: Initiative, Plan, Act and Certify. The 4steps methodology is the first practical guide for businesses that wish to use a local/national less formal EMS in more than one Nordic country.

The 4Steps were presented for the first time at a workshop held in Helsinki on 12-13 March 2008. It has given the project a tool with which to compare the systems more practically and provides a framework for discussing the obligatory demands of each system. To follow up, it has been developed so that also businesses can use it as a first guide to using the Nordic systems in the region.

The main purpose of step 1, Initiate, is to establish a contact between the company and involved consultants or advisors from the municipality and to sign a contract.

The main purpose of step 2, Plan, is to establish a project plan and to carry out an environmental review, including an assessment of various environmental aspects, and to create action plans in relation to the most important of these aspects.

The main purpose of step 3, Act, is to educate employees, implement the system and its necessary routines in the organisation and to execute the action plans.

The main purpose of step 4, Certify, is to perform certification.

In Appendix 3, each system's criteria and requirements are separately explained according to the 4Steps model. The follow-up work to certification is also clarified.

In Appendix 4, the systems are compared to each other step by step according to the 4 Steps model. The appendix is designed especially to help companies compare the requirements of the three Nordic systems. 



\section{The common platform for the Nordic less formal EMSs opens up for further development}

The process on developing a common platform has passed many milestones. The steering group has convened many times, enhancing trust between the different parties and serving as a venue for very important dicussions and the making of crucial decisions. The workshop was arranged in order to introduce the issue also to Nordic actors that are not involved in the project. In addition to this, a cooperation agreement will be signed in Odense in September. A process initiated in the Helsinki metropolitan area also forms a part of the coordination effort. A threeyear project to establish a less formal EMS according to the common Nordic agreement will commence in June 2008. Even though many promising steps have been taken towards coordination and common platform of the Nordic systems, there's still a lot of work to be done.

\subsection{Workshop}

The workshop was held in Helsinki on 12-13 March 2008. 34 participants were there to represent five different countries and nine different Nordic EMS systems. Representatives of local and national authorities and businesses also took part.

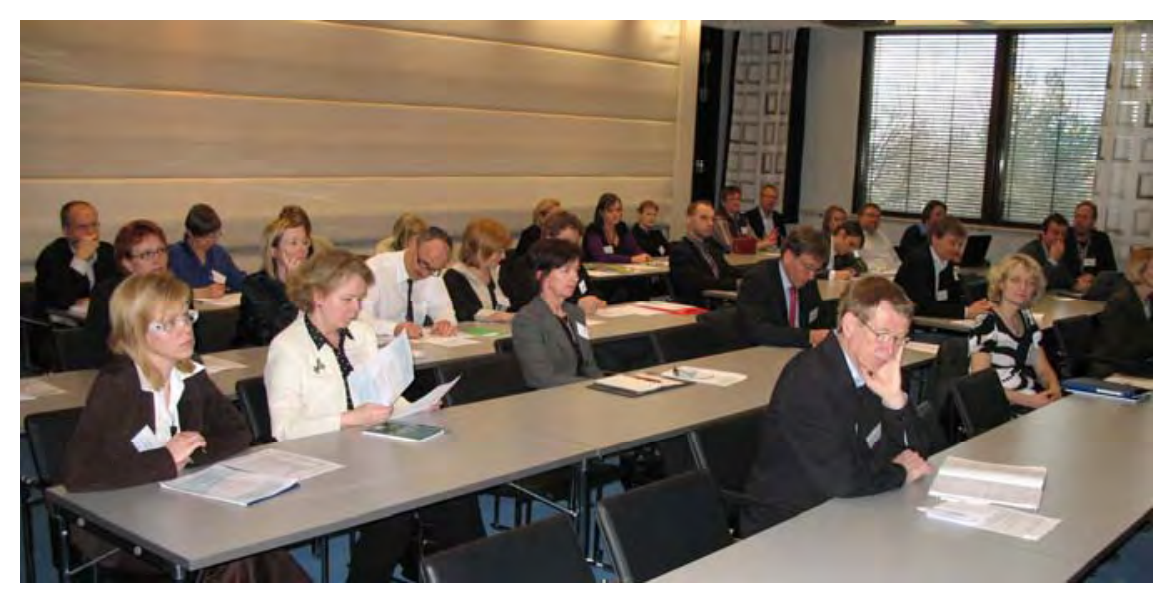

The original idea of the workshop was to bring different municipal sectors, researchers and business together for a kick-off event that would launch the co-operation. As the project progressed, however, it was 
agreed that the workshop would be most effective after the completion of a certain amount of background work. For this reason, the project steering group decided to prepare a presentation called 4steps for the workshop it dealt with the Eco-lighthouse, Green Network and Environment Diploma processes. The objective of the presentation was to demonstrate the basic similarities of each system by deviding the processes into four steps, attempting to use the same terms to describe similar issues. How the five different Nordic systems correspond with the ISO 14001 standard was also explained at the workshop.

The schedule of the workshop was intensive and its atmosphere was very open to discussion. In addition to the steering group's evaluation, there were presentations about how important SMEs are to communities (Jan Dictus, Vienna), business perspectives (Steen \& Strøm and the business region of Gothenburg) and presentations by the five different Nordic less formal EMS systems as well.

To conclude, the steering group presented its idea for future cooperation between the different Nordic systems. Discussions about a common Nordic organisation, marketing efforts and a logo ensued. And, of course, there were discussions about which common principles and criteria should be adopted for all the systems in future. The steering group stated that an agreement on future co-operation would be drafted in June 2008.

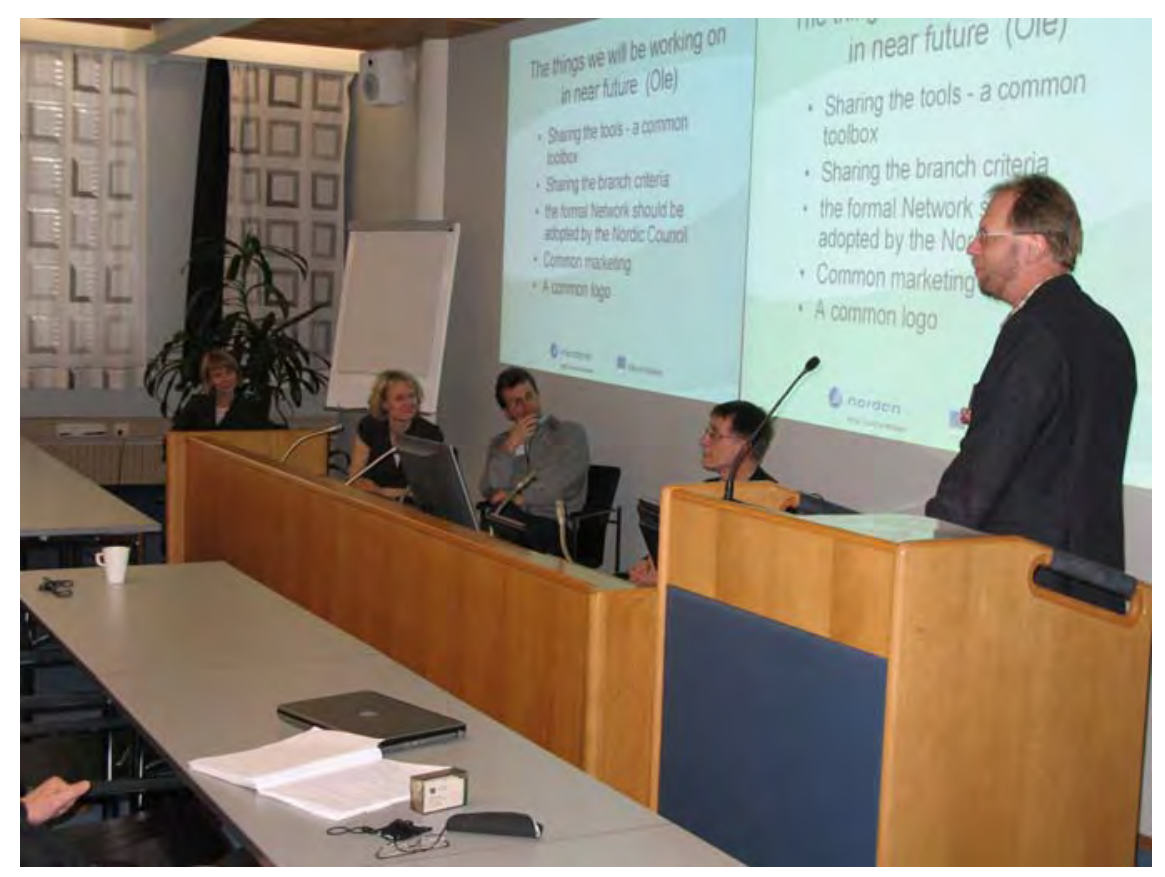

Feedback from the participants was good; many said they got good ideas and discovered new partners for co-operation. There was great interest in working together and in following up on the Nordic E-COOP for SMEs project. 


\subsection{Frontrunner enterprises - case Steen \& Strøm}

When the project commenced, Steen \& Strøm asked the Eco-Lighthouse programme if they could use it also in Sweden and in Denmark.

At the initial meeting of the steering group, it was decided that Steen \& Strøm could use all three local systems in order to avoid unnecessary difficulties in implementation for the company. This initiated a detailed comparison of the different systems for real.

The three systems and Helsinki made a cooperation agreement with Steen \& Strøm. The parties agreed on the following:

Steen \& Strøm will continue the ECO-Lighthouse process with a pilot project in order to certify one shopping centre in each country.

Steen \& Strøm will establish ECO-Lighthouse routines in its shopping centres in Denmark and Sweden and make necessary additions in order to make them compliant with the requirements of the Swedish and Danish systems.

The shopping centres must comply with the industry-specific criteria of the EcoLighthouse programme as well as with the additional demands necessary in Sweden and Denmark.

Annual reporting will be based on the Eco-Lighthouse reporting system, but necessary additions must be included in order to achieve compliance with the Swedish and Danish systems.

In Sweden and Denmark, Steen and Strøm will cooperate with the local systems and certification/audits will be carried out locally. Steen \& Strøm's initial report should comply with the demands of each system.

Even though Steen \& Strøm is big company, its decisions have an impact on thousands of small and medium shops (including the 54 shopping centres it-selves). It can demand environmental actions from its tenants, even imposing a requirement for certification in some cases. Shopping centres are popular among consumers and this is an effective way to influence also regular customers. Shopping centre proprietors can support shopkeepers' efforts to enhance their environmental performance - without their support, this would be very challenging.

There are plenty of big real estate companies that could, like Steen \& Strøm, require their tenants to implement a less formal environmental management system. As was seen at the workshop, an interest to do so has already arisen in Finland as well.

\subsection{Starting the process in Helsinki}

Together with the area's wholesalers, the City of Helsinki's Environment Centre and Business Development Unit started a project called "Improv- 
ing the environmental performance of SMEs in Helsinki” in 2006. The project was launched because of a need to improve the environmental performance of SMEs in Helsinki and it had the aim of promoting cooperation between different municipal sectors as well as between municipalities and businesses. The need for the project was established in the Sustainable Development Action Plan of Helsinki, which was approved by the City Council in 2002.

A feasibility study for the project was published in 2007 and an EUfunded three-year project for the Helsinki Metropolitan area will be launched in 2008. The goal of the project is to develop an operating model for Helsinki and other big cities that provide support for the environmental performance of SMEs in co-operation with different municipal sectors and businesses based on the experiences of the mentioned Nordic initiatives and the 4-step process, which was developed during the project.

\section{Training for business advisors}

Helsinki Business Development Unit employs about 16 business advisors, who train, guide and advise micro businesses and SMEs, most of which are fresh start-ups. The Agency annually arranges four business courses for new and immigrant entrepreneurs. In addition, seven business incubators are active in Helsinki and they currently provide support for some 200 new firms.

Municipalities have a major role in motivating and disseminating information to SMEs. The view was that business advisors could, because of their daily contacts with entrepreneurs, play a very important role in getting the environmental information through to businesses. This created a need to provide business advisors with environmental training.

However, the municipal structure of every Nordic country is different and because of this the first environmental training event was held in Helsinki in February. About 12 representatives of Helsinki's Business Development Unit participated. The day demonstrated that a need for this kind of information and support definitely exists. The day consisted of six lectures on different environmental issues of relevance to businesses.

The business advisors were supplied with material and checklists that will help small enterprises to take environmental issues into consideration as part of their daily business. A feedback event was held on 4.6. There was a discussion about the fact that this is just the beginning of the process. The training event was the first of its kind in Helsinki and a second course for the metropolitan area is scheduled for autumn 2008. It will need more than just few events and training days to give the tools for the business advisors to have the discussions with the entrepreneurs about the environmental issues. At the feedback event it was found also important that these issues implement also the strategies of the City of Helsinki. 
The experiences will be utilised in future cooperation - for example, common environmental training and experience-sharing events could be arranged for Nordic business advisors. In addition to facilitating the dissemination of valuable knowledge, this would improve the status of environmental issues among advisors.

\subsection{Signing the agreement}

An agreement to continue and develop the coordination of the less formal approaches to EMSs in the Nordic countries will be signed at the Sustainability Conference in Odense in September. The purpose of the coordination is to set a common direction for future development.

The agreement has been established between system owners that operate systems where;

- The local municipality has a central role in running the systems.

- The systems are mainly organised locally and regionally.

- The parties have or will establish a common strategy for spreading the systems nationwide.

- The systems are based on the environmental analysis an SME's conduct, yearly reporting and are audited externally/independently.

- The systems are based on the idea of growing responsibility and improvement.

- The local municipality conducts the auditing and awards the certificate/diploma.

Organisation of the cooperation:

The chairmanship should circulate between the parties on a two-year rotation.

Gothenburg will start and chair the cooperation in September 2008 September 2010.

Appendix 1 presents the Agreement and the parties to the agreement. 



\section{Looking back on the project - evaluation and conclusions}

\subsection{The main success factor: Nordic cooperation}

Members of the project steering group participated in a questionnaire, which indicated that, generally speaking, the project has been successful. The expectations that the partners had were mostly fullfilled. Especially the cooperation itself exceeded expectations. The partners agreed on the project's objectives and viewed them as top priorities in their work. This kind of cooperation, where everybody is expected to remodel their systems so that they would correspond more closely, requires trust, goodwill and enthusiasm - this was definitely not problem in this project.

\subsection{Working methods: something special and some room for development}

The project did not rely on consultants as much as was planned because the steering group started a comparison of the systems by discussing the similarities and differences of the different systems. These intensive work carried out at these initial meetings established the basis for the project. Achieving a deep insight into every system made the discussions about the common platform possible. Good communication and positive attitudes among the steering group made cooperation easier.

On the other hand, cooperation takes time and teamwork routines develop gradually as the project progresses. According to the questionnaire, the steering group could have gotten even more results out of its meetings had it been more disciplined at times. At some stages of the project, the meetings of even the smaller thematic groups could have been more efficient.

Reporting of the results is crucial - especially when work is carried out through a foreign language and between different cultures. The project could have been more accurate about this in order to establish a better common understanding about what had been decided at meetings. 


\subsection{The benefits}

According to the questionnaire, the benefits of cooperation included:

\section{Partners}

- Raised the status of the scheme - promoted a sense of belonging to something big (Nordic network)

- More certifications (businesses involved) in future (for example S\&S-own shopping centres)

- Experiences

- Good ideas

- Stimulating

- Learning about how other Scandinavian countries work with EMS for SMEs

- Picking up the best practices

\section{Businesses}

- Certification to become more valuable in future (common logo, better known, comparable with other countries)

- Better systems - more results

- More results with the same money (a common toolbox in next phase)

\subsection{The role of frontrunner businesses}

As the questionnaire demonstrated, the role of a frontrunner business (Steen \& Ström) was seen as that of a "catalyst" and an "energiser" to cooperation. The firm challenged the process by pointing out some major goals and issues that have to be resolved for the coordination process. It is very important to evaluate the results of this in order to accumulate information on how the process has succeeded.

However, it was also seen that, after the necessary documentation (routines and requirements) is developed, their role in the cooperation would become less significant.

Frontrunner businesses are important also because they lead the way and attract other businesses into these systems. The marketing benefits go both ways. In this case, it was a good thing that the business itself was big enough to put resources into the development process, but, at the same time, had contacts with and influence on thousands of different small shops - precisely the target group this project wanted to reach. 


\subsection{Outlook for the future - hopes and fears}

According to the questionnaire, the most ideal situation for the future would be the establishment of a Nordic formal organisation with a common toolkit, shared marketing and logo. An important criterium for the organisation is that those belonging to it should promote strong cooperation between municipalities and the businesses participating in the systems. This distinguishes the systems from, for example, EMAS or ISO 14001.

The threats the established less formal Nordic EMS initiatives are facing were, according to the questionnaire:

- Lack of adequate financing

- EU regulations that might prohibit the municipalities from supplying these kinds of services

- Disparate development of the systems might weaken them all

In future, the establishment of a common organisation with shared branding and harmonised routines and criteria for different systems might be possible. In the meantime exchange of experiences and tools, common branding will be very useful, especially for the businesses using the systems.

In addition, the process has demonstrated that even a common Nordic system should be considered in future. However, this needs support. The forming of a common organisation requires funding (toolkit, cookbook for routines, translation of the needed material, etc.). After the organisation has established its routines, it should be self-financing.

\subsection{Recommendations - future success factors}

Common Nordic organisation - national level

- Working plan

- Chairman selected for every second year

- Common financing for the Nordic cooperation, yearly budgeting

- Toolkit

- Common logo and marketing

- Common platform

- A cookbook for routines

- A contact person who advises the businesses - secretary 


\subsection{Dissemination of results}

- Workshop in Helsinki 12-13 April 2008

- Presentation at the Greening the local economy meeting in Helsinki in April 2008 - A working group of EUROCITIES

- A working group at the Nordic Sustainable Conference in Odense in September 2008 


\title{
References
}

\author{
www.eco-lighthouse.com \\ www.miljofyrtarn.no \\ www.miljodiplom.se \\ www.miljo.goteborg.se \\ www.svenskmiljobas.se \\ www.greennetwork.dk \\ www.key2green.dk \\ www.ems-light.org
}

Presentations from the workshop

Nordic E-Coop for SMEs in Helsinki

12-13 March 2008

E-mail correspondence with represent-

tatives for the assessed systems

E-mail correspondence with companies

using the assessed systems

Questionnaire for the steering group 


\section{Appendices}

1. Agreement

2. The Evaluation of five established less formal EMS initiatives within the frames of the project Nordic E-Coop for SMEs

3. Comparison of criteria and tools for less formal EMSs within the frames of the project Nordic E-Coop for SMEs. 4Steps -model.

4. 4Steps- Matrix for the businesses 


\section{Agreement}

This agreement has been signed in order to continue and develop the coordination of the less formal approaches to EMS in the Nordic countries.

The purpose of this coordination is to set a common direction for the future development.

The agreement has been established between system owners that run systems where;

$\checkmark$ The local municipalities have a central role in running the systems.

$\checkmark$ The systems are mainly organised locally and regionally.

$\checkmark$ The parties have established or will establish a common strategy for spreading the systems nation wide.

$\checkmark$ The systems are based on SMEs implementation of environmental analysis, yearly reporting and external and independent auditing.

$\checkmark$ The systems are based on enhancing responsibility and improvement.

$\checkmark$ The local municipality organizes the auditing and awards the certificate/diploma.

The parties agree to emphasize these important aspects of their EMS systems.

Other important objectives are:

To meet future needs from businesses and municipalities

To meet EU directives regarding future legislation

\section{Organisation of the cooperation:}

The chairmanship should be circulated among the parties every second year.

Göteborg will start chairing the cooperation from September 2008 - September 2010.

All decisions will be based on consensus.

At least one meeting will be held each year.

This agreement will be evaluated after 2 years and then signed again.

Prioritised issues:

$\checkmark$ Common website containing

- A toolbox with a matrix showing each of the systems mandatory and optional demands.

- The different procedures within each system.

$\checkmark$ Work plan and budget for the first period. (September 2008 - September 2010)

The parties are committed to participate in planning the activities for the next period and set aside resources through their budget processes.

$\begin{array}{lllll}\text { Eco Lighthouse } & \text { Pekka Kansanen } & \text { Green Network, } & \text { Christina } & \text { Järfälla kommun } \\ & \text { Director General } & \text { Vejle } & \text { Börjesson } & \\ \text { Environment } & & \text { Director } & \\ \text { Centre } & & \text { Environment } & \\ \text { City of Helsinki } & & \text { Administration of } & \\ & & \text { Göteborg } & \end{array}$


Annex 1, Work plan

$\checkmark$ Presenting the tools - discuss possibilities of sharing a common toolbox.

$\checkmark$ Sharing the branch criteria

$\checkmark$ To discuss the formal Network to be adopted by the Nordic Council

$\checkmark$ Common marketing

$\checkmark$ A common logo

Annex 2, principal organisational structure

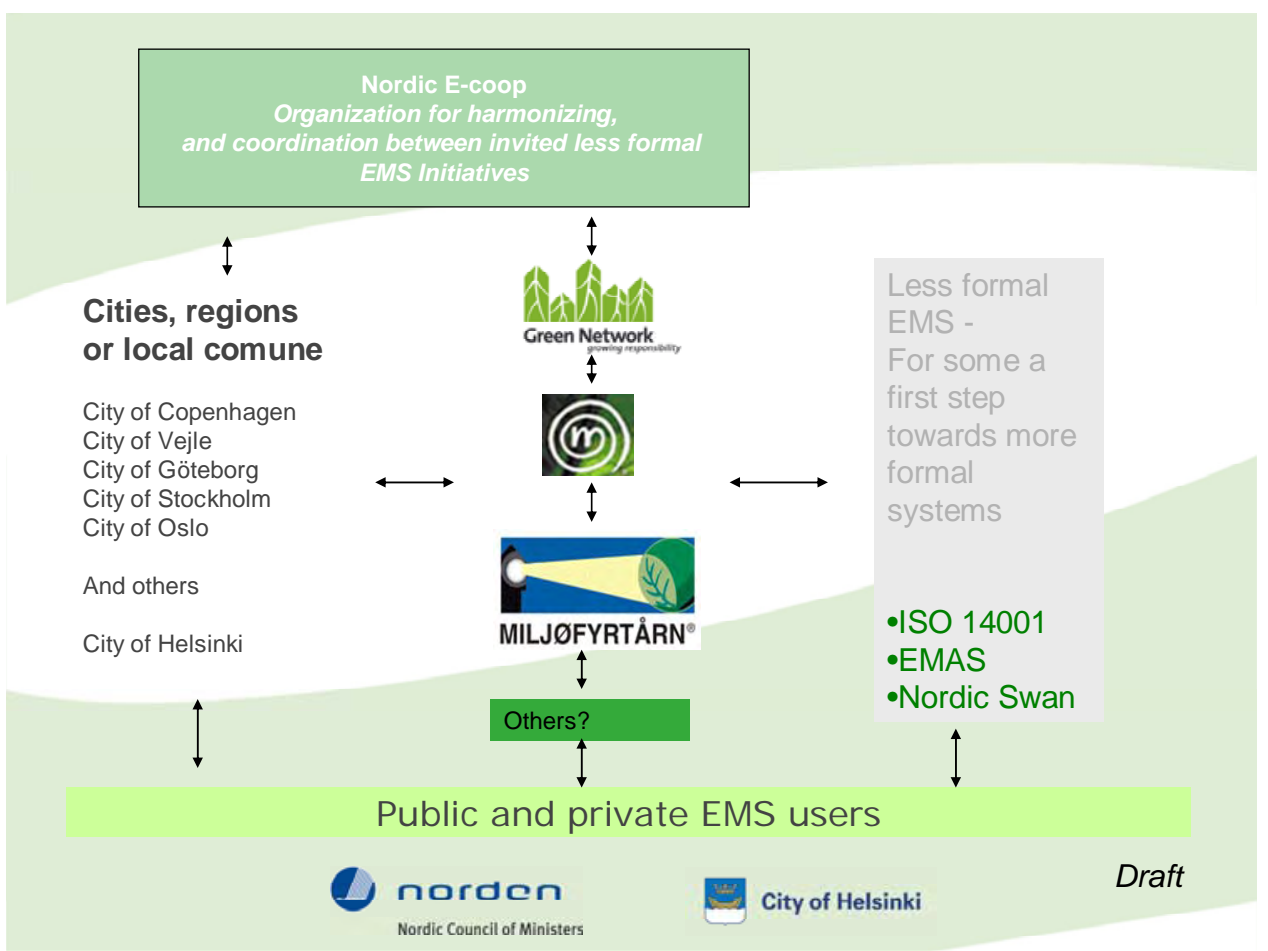


EcoProfile $\varnothing$

\section{Evaluation of five established less formal EMS initiatives within the frames of the project Nordic E-Coop for SMEs}

16 May 2008

Ann-Christine Eriksson

Oy Eco Profile Ab 


\section{Evaluation of five established less formal EMS initiatives within the frames of the project Nordic E-Coop for SMEs}

\section{Contents}

1. Introduction

2. Evaluation of the EMS initiatives

2.1 Similarities and differences regarding the demands of the systems

2.2 Benefits to the companies and to the municipalities

2.3 Amount of users

$2.4 \quad$ Regular follow-up, reporting

$2.5 \quad$ Funding

2.6 Marketing methods

2.7 Need for environmental education

2.8 Publications

2.9 Communication

2.10 The role of the municipalities, need for co-operation

2.11 Good examples

3. Main results

4. Conclusions

Sources 


\section{Introduction}

This study is part of the project Nordic E-Coop for SMEs with purpose at developing the Nordic co-operation between existing less formal EMS initiatives for SMEs. The goal of the project is to enhance the eco-efficiency and the competitiveness of SMEs in the Nordic countries by assessing established EMS initiatives, by searching ways to harmonize them and by searching ways to strengthen the co-operation between local authorities and enterprises. During the latest decades successful certification systems have been created in special regions in the Nordic countries. The implementation of the models has created valuable know-how and competence. In order to develop and harmonize the Nordic models it is important to take advantage of existing experience.

The aim of this study is to assess five less formal EMS frameworks with focus on differences in the systems and the roles of involved interest groups. The subjects of the study are:

\begin{tabular}{lll} 
EMS & Country & Representative \\
\hline Eco-lighthouse & Norway & $\begin{array}{l}\text { Eco-Lighthouse, Kristiansand, } \\
\text { Morten Leuch Elieson }\end{array}$ \\
$\begin{array}{l}\text { Key2Green } \\
\text { Diploma }\end{array}$ & Denmark & $\begin{array}{l}\text { Green Network, Vejle, Ole Dall } \\
\text { City of Göteborg, Göteborg, }\end{array}$ \\
EcoStart & Finland & $\begin{array}{l}\text { Eeer-Erik Carlsson } \\
\text { Employment and Economic Development }\end{array}$ \\
EMS light Nordic & $\begin{array}{l}\text { Åland, Island, } \\
\text { Faeroe Islands }\end{array}$ & $\begin{array}{l}\text { PlanMiljö, Denmark, Tomas Sander Poulsen, } \\
\text { and Ann-Christine Eriksson, the local } \\
\text { consultant in Åland }\end{array}$
\end{tabular}

The EMS initiatives are assessed regarding

- similarities and differences regarding the demands of the systems

- benefits to the enterprises and to the municipalities

- amount of system users

- requirements on reporting, regular follow-up

- costs for involved partners, potential financial support

- responsibilities regarding marketing of the systems

- need of external environmental training in the enterprises

- publications regarding experience of the systems 
- communication between interest groups in the network

- the role of the municipalities, need for co-operation

- practical examples

The assessment is based on features of and experience from the five environmental management systems and it provides background information regarding harmonization of the systems and strengthening of the co-operation between the enterprises and local authorities.

\section{Evaluation of the EMS initiatives}

\subsection{Similarities and differences in the demands of the systems}

All five subjects of this survey have many features in common. They correspond to the main criteria of ISO 14001 and EMAS, but are less bureaucratic and less expensive. All systems are easy to develop towards ISO 14001 and EMAS, if later on needed. The main difference to ISO 14001 and EMAS is that the less formal EMSs are minimizing requirements on documentation and document managing. This makes the EMSs easy to understand and easy to use. That's also the reason why there is a growing demand of less formal EMS initiatives.

\section{Requirements of the different systems}

\begin{tabular}{|l|c|c|c|c|c|}
\hline Issue & $\begin{array}{l}\text { Eco- } \\
\text { Lighthouse }\end{array}$ & $\begin{array}{l}\text { Green } \\
\text { Network }\end{array}$ & $\begin{array}{l}\text { Envir. } \\
\text { Diploma }\end{array}$ & EcoStart & $\begin{array}{l}\text { EMS-light } \\
\text { Nordic }\end{array}$ \\
\hline Environmental policy & $\mathrm{x}$ & $\mathrm{x}$ & $\mathrm{x}$ & $\mathrm{x}$ & \\
\hline Environmental aspects & $\mathrm{x}$ & $\mathrm{x}$ & $\mathrm{x}$ & $\mathrm{x}$ & $\mathrm{x}$ \\
\hline Legal requirements & $\mathrm{x}$ & $\mathrm{x}$ & $\mathrm{x}$ & $\mathrm{x}$ & $\mathrm{x}$ \\
\hline Targets & $\mathrm{x}$ & $\mathrm{x}$ & $\mathrm{x}$ & $\mathrm{x}$ & $\mathrm{x}$ \\
\hline Action plans & $\mathrm{x}$ & $\mathrm{x}$ & $\mathrm{x}$ & $\mathrm{x}$ & $\mathrm{x}$ \\
\hline Defined responsibilities & $\mathrm{x}$ & $\mathrm{x}$ & $\mathrm{x}$ & $\mathrm{x}$ & $\mathrm{x}$ \\
\hline $\begin{array}{l}\text { Environmental } \\
\text { representative }\end{array}$ & $\mathrm{x}$ & $\mathrm{x}$ & $\mathrm{x}$ & $\mathrm{x}$ & $\mathrm{x}$ \\
\hline Training of staff & $\mathrm{x}$ & $\mathrm{x}$ & $\mathrm{x}$ & $\mathrm{x}$ & $\mathrm{x}$ \\
\hline $\begin{array}{l}\text { Routine for external } \\
\text { communication }\end{array}$ & $\mathrm{x}$ & $\mathrm{x}$ & $\mathrm{x}$ & & \\
\hline $\begin{array}{l}\text { Health and safety } \\
\text { included }\end{array}$ & $\mathrm{x}$ & $\mathrm{x})$ & & & \\
\hline $\begin{array}{l}\text { Checklists for } \\
\text { compliance }\end{array}$ & $\mathrm{x}$ & $\mathrm{x}$ & $\mathrm{x}$ & $\mathrm{x}$ & $\mathrm{x}$ \\
\hline Environmental reporting & $\mathrm{x}$ & $\mathrm{x}$ & $\mathrm{x}$ & $\mathrm{x}$ & $(\mathrm{x})$ \\
\hline Regular follow-up & $\mathrm{x}$ & $\mathrm{x}$ & $\mathrm{x}$ & $\mathrm{x}$ & $\mathrm{x}$ \\
\hline External auditing & $\mathrm{x}$ & $\mathrm{x}$ & $\mathrm{x}$ & $\mathrm{x}$ & $\mathrm{x}$ \\
\hline Certificate/Diploma & $\mathrm{x}$ & $\mathrm{x}$ & $\mathrm{x}$ & $\mathrm{x}$ & \\
\hline Re-certification & $\mathrm{x}$ & $\mathrm{x}$ & $\mathrm{x}$ & $\mathrm{x}$ & \\
\hline
\end{tabular}

$\mathrm{x}=$ requirement 
$(\mathrm{x})=$ voluntary

1) = all regular personnel must fulfil at least 4 hours of Basic Environment Training before the certificate is awarded

2) = manual

3) $=$ checklists for the auditing consultants

\section{Similarities in the content of the systems}

The main part of the systems is quite similar, although in some cases different terms are used for same things. The most important similarities are listed below:

- They are focusing on concrete measurable environmental improvements, not on high requirements on documentation

- The environmental program is the main issue, around which the environmental work is built up

- In all five models the environmental program or statement requires

- Environmental analysis regarding environmental aspects and impacts

- Targets

- Action plan

- Knowledge and fulfilment of legal requirements

- Defined responsibilities, environmental representative

- Regular environmental training

- Checklists

- Environmental report

\section{Differences in the content of the systems}

Regarding harmonization of the systems the differences between them are more interesting than the similarities. The following list is focusing on factors that distinguish the systems.

\section{Eco-Lighthouse}

- Includes both external and working environment

- General criteria + branch-specific criteria

- Re-certification every third year

- Official annual environmental report

- Checklists

\section{Green Network}

- Tools including manuals describing the phases that the companies must pass to achieve continuous improvements

- Possible to include Occupational Health and Safety and/or Social Commitment

- Requirements on sub-contractors

- Official environmental statement, (the public authorities also has access to the more detailed handbook)

- Diploma valid for two years, after that re-certification is required

- In addition to the diploma, companies receive a Green Network flag 


\section{Environmental Diploma}

- A list of obligatory issues

- A general checklist which can be used in all branches

- Demands on Basic Environment Training from start

- Re-certification every year

- Official annual environmental report

\section{EcoStart}

- Strong emphasis on material- and energy-efficiency and cost savings

- Actions regarding slowing climate change are included

- The companies' time resources are taken into consideration

- No official reports or statements

- Re-certification every third year

\section{EMS light Nordic}

- The Excel-based follow-up tool for energy- and material consumptions and costs is the core of the system. The tool provides continuous follow-up of the eco-efficiency.

- Annual reports based on the input information are automatically produced.

- No environmental policy

- No demand on official reporting

- No certification

\subsection{Benefits to the companies and to the municipalities}

The benefits to the companies of having a less formal EMS seem to be the same in all five EMS models:

- The companies appreciate a simple EMS, which is focusing on measurable cost-effective improvements and is easy to understand and to use

- All models offer competitive edge

- All models provide a good communication channel to interest groups

- All models give the enterprises a good start, if ISO 14001 or EMAS implementations are needed later on

- All models strengthen the company image

- All models motivate the personnel and strengthen the team spirit

EcoStart and EMS light Nordic are much younger systems than the other. There is at most 1-2 years experience of using these two systems. Under these circumstances it is too soon to find out long-term benefits.

The benefits to municipalities are different depending on the degree of involvement in the project. 


\section{Eco-Lighthouse}

The EMS strengthens the co-operation between the enterprise and the municipality. Although a consultant is involved in the project, the relation to the municipality is close. The municipality's responsibility, among other things, is to certify and award certificate when trade criteria are fulfilled.

\section{Green Network}

Private companies and the public sector work closely together in order to achieve sustainability. Key employees from the public service partners are available to assist the companies. Green Network emphasizes dialogue, voluntary agreement and commitment. The combination of knowledge and skills of the companies and Green Network ensure good co-operation and close relations.

\section{Environmental Diploma}

In addition to the role as authority, the municipality also has an important role as advisor to companies. In the EMS project the municipality has two advisor roles: project advisor at the beginning of the project and auditor at the end of the project. The companies' fulfilment of environment legislation is checked with colleagues in the Environment Administration. During the project the company works independently with the obligatory issues using the checklist. After the municipality has carried out a successful audit in the company, the municipality awards diploma. The municipality's strong presence in the project strengthens the relation between the company and municipality.

\section{EcoStart}

The EcoStart concept is developed by the Regional Employment and Economic Development Centre (T\&E Centre) of South Savo, but is now used in four other T\&E Centre regions, too. The involved T\&E Centres educate both authorized consultants to advise companies in the EcoStart project and authorized auditing consultants to carry out the certification audits. The T\&E Centre awards certificates together with the local Chamber of Commerce or Enterprise Association. This arrangement strengthens the relationship between different actors in society.

\section{EMS Light Nordic}

EMS Light Nordic differs from the other systems as it is focusing on SMEs in small communities (Iceland, Faroe Islands and Åland) far from big cities in the Nordic Countries. The initiator of the project is the Small Communities Group of the Nordic Council that consists of representatives from the communities' environmental authorities. The environmental authorities don't actively participate in the project, but they take part in seminars in order to create good contacts with the companies. The project consultants are chosen by the authorities. 


\subsection{Amount of users}

Eco-Lighthouse

Green Network

Environmental Diploma

EcoStart

EMS Light Nordic

\section{Established}

1996

1994

1995

2006

2007
Users 2007

1120

285

$305^{*}$

48

16

* in Göteborg and the Göteborg Region, 13 municipalities

\subsection{Regular follow-up, reporting}

\section{Eco-Lighthouse}

An annual environmental report is made in the beginning of the year. Eco-lighthouse templates are used for the report. The annual environmental report is distributed to the environmental officer in the municipality, the company's owners/board and employees.

The action plan must be included in the ordinary budget plan.

Re-certification is required every third year.

\section{Green Network}

An environmental statement is required to get diploma and flag. The environmental statement is the essence of the environmental work and valid for two years. Detailed environmental information is collected in an environmental manual that is available to the municipality. In order to be awarded re-certification the company has to prove that environmental actions have been done and targets achieved according to the statement.

\section{Environmental Diploma}

Every year the company sends an up-dated list of chemicals, a waste survey, a checklist, an environmental plan for the following year and an environmental report regarding last year's environmental actions to the municipality. The municipality makes annual follow-up audits in the company.

\section{EcoStart}

EcoStart requires a documented environmental program, which regularly has to be updated. In addition the company creates a follow-up report, based on defined followup indicators, for the certification occasion. Neither of these documents is official. Re-certification is required every third year.

\section{EMS Light Nordic}

No regular reporting is required, but the Excel-based tool produces automatically annual reports based on the input information. It is up to the company to decide the distribution of the reports.

No certification is required. 


\subsection{Funding \\ Eco-Lighthouse}

Eco-lighthouse is self-financed since 2005.

The companies pay a connection fee of $1800-10800$ NOK, and after certification an annual service fee of $800-10000 \mathrm{NOK}$, depending on the size of the company. The price of the certificate is $500 \mathrm{NOK}+300 \mathrm{NOK}$ service fee. The consultant and the company negotiate for the consulting fee. In some municipalities the company has possibility to get financial support from the municipality for the environmental analyses that the company carries out together with the consultant.

\section{Green Network}

Green Network is one of the organisations acting under Key2Green, which is a selffinanced umbrella organisation for seven regional networks. Companies, so called Vmembers, pay an annual membership fee of 3000 DKK ( $<150$ employees) or 4000 DKK ( $>150$ employees) and receive free assistance from the municipalities in organising their EMS. Green network is a regional network including six municipalities, O-members, which support the project with 6,80 DKK per inhabitant. Interested organisations and companies, I-members, pay 2500 DKK per year.

\section{Environmental Diploma}

Environmental Diploma is self-financed. All income comes from the involved companies. The registration fee for environmental diploma is 4000 SEK which is charged when a declaration regarding the environmental issues has been accepted by the municipality. After an initial meeting the enterprise receives an offer of the remaining work. The minimum fee is 8000 SEK including the registration fee. The average fee is 12000 SEK. The fee depends on size, activities and the scope of the authorities' work with the enterprise. Companies pay in average 7500 SEK for recertification. The cost for Basic Environment Training is added to the sum for the first diploma. Most of the courses are held by consultants.

To join the network consisting of interested municipalities the municipality has to pay $3500 \mathrm{SEK} / \mathrm{a}$. The network consists of 29 municipalities, half of them in the Region of Göteborg.

\section{EcoStart}

EcoStart is a subsidized environmental consulting service for SMEs in Finland. It belongs to a group of consulting service products of Ministry of Employment and the Economy. The provincial federation of South Savo has financed the development of EcoStart. Since 2006 each involved T\&E Centre subsidises the implementation of EcoStart in the companies with maximum $70 \%$.

The participating companies pay 100-300 € per workshop for consulting service depending on the size of the company. At minimum four consulting days are needed. The audit day is $50 €$ more expensive than the consulting days. 


\section{EMS Light Nordic}

The project is subsidised by the Nordic Council and the local environmental authorities in Iceland, Faeroe Islands and Åland. The development of the model is covered by the support from the Nordic Council. The local environmental authorities subsidise the project with 100000 DKK. The companies pay a participation fee of 10 000 DKK each, which is aimed at partly cover the consulting fees.

\subsection{Marketing methods}

\section{Eco-Lighthouse}

The Eco-Lighthouse Office has an overall responsibility for marketing and for the continuous development of the program, including developing and improving industry criteria in co-operation with consultants, companies and branch organisations. The office also arranges courses for consultants and municipal representatives responsible for certification.

Municipalities is encouraged to involve media and mayor every time a certificate is awarded.

Recruting efforts verys, and new companies can be recruited in different ways depending on the region. Consultants and municipalities are the main recruters. Lately some national organisations has signaled that they will put recources into recruting businesses.

\section{Green Network}

The municipalities' environmental specialists are responsible for selling the concept Green Network to the enterprises. The secretariat takes care of advertising activities. Companies that fulfil the Green Network criteria get a Green Network flag, which is a good way to make Green Network known also among other people than customers and consumers.

\section{Environmental Diploma}

The registration fee includes advertising costs. The environmental government is responsible of the marketing of Environmental Diploma and arranges different types of advertising, seminars, exhibitions, articles and brochures. The companies can use their diploma logo in their marketing activities. Environmental Diploma will be included in www.certifiering.nu, a new website for different kinds of certifications.

\section{EcoStart}

Five regional Employment and Economic Development Centres are offering EcoStart in their regions. A proposal has been sent to the Ministry of Trade and Industry to expand EcoStart as a national product.

\section{EMS Light Nordic}

According to the project plan the company organisations and local environmental authorities with support from the local consultants are responsible for marketing of EMS Light Nordic. In practice the consultant's marketing activities are crucial for the project success. 


\subsection{Need of environmental education}

All five systems demand regular general environmental education of the whole staff and specific education of persons with specific environmental responsibilities. Also new employees have to be educated in the main parts of the EMS. A good way to motivate the staff is to involve employees in the project from the beginning. For instance Environmental Diploma requires at least 4 hours Basic Environment Training for the personnel before the diploma is awarded.

\subsection{Publications}

Several reports about the experience of Eco-Lighthouse and Environmental Diploma have been published. According to the reports the EMS has fulfilled the expectations of both companies and municipalities. Detailed information can be found on the website addresses below.

\section{Eco-Lighthouse}

Published reports regarding experience of Eco-lighthouse are collected at the website www.miljofyrtarn.no/Programinfo/dokumentasjon.htm.

\section{Green Network}

Reports are not yet published, but a book about the Green Network concept will be published until United Nations’ Climate Change Conference in Copenhagen 2009.

\section{Environmental Diploma}

Published reports regarding experience of Environmental Diploma are collected at the website www.miljo.goteborg.se/Miljödiplomering.

\section{EcoStart}

A summary of EcoStart projects during 2006-2007 has recently been published, www.te-keskus.fi/Etelä-Savo/Ajankohtaista.

\section{EMS Light Nordic}

Reports are not published. The project started in companies in 2007.

\subsection{Communication}

\section{Eco-Lighthouse}

The external communication includes the annual environmental report that is being distributed to the environmental officer in the municipality, the company's owners/board and employees.

\section{Green Network}

There is a continuous dialogue between companies and key persons in the municipality that ensures a constructive co-operation between the municipality and the companies. 


\section{Environmental Diploma}

The communication between the municipality and the company is frequent because of the audits, which the municipality's specialists annually carry out in the companies, and the annual reports.

\section{EcoStart}

There is no demand of regular reporting to or meeting with the municipalities or other authorities.

\section{EMS Light Nordic}

There is no demand of regular reporting to or meetings with the municipalities or other authorities.

\subsection{The role of municipalities, need for co-operation}

\section{Eco-Lighthouse}

The municipalities can participate in recruiting new enterprises. They assign consultants to the companies, oversee media coverage, and conduct certification inspections. The municipalities also award the certificates.

The role of the local consultants is to conduct environmental analyses with input from the environmental group formed by company management and employees.

Eco-lighthouse forms a network between municipalities, trade organisations and companies. The National Board includes representatives from different interest groups. The Eco-lighthouse office and the National Board approve new and reviced criterias after haveing recieved coments from users, trade organisations and other parts.

\section{Green Network}

The organisation includes among other groups an idea forum that mainly consists of representatives from Green Network's V-members. V-members are companies that have prepared a statement in accordance with at least one of the Green Network manuals. The statement must be approved by Green Network. One role of the idea forum includes that the development of Green Network reflects the interests of both the industry and the public sector.

Working on the statements is a core project within Green Network. The process includes a close dialogue between the individual company and municipality key staff. This dialogue is based on the idea that all resources of the cooperation must be used optimally and constructively. The municipality's specialists have current knowledge of the Green Network tools. The co-operation guarantees result-oriented solutions. Many companies also enter into a close dialogue with sector experts or other specialists. 


\section{Environmental Diploma}

The environmental administration assists the enterprises in the environmental management work and acts as advisor at the beginning of the project and auditor at the end of the project. After certification the close co-operation continues through annual contacts and audits.

\section{EcoStart}

The role of the T\&E Centres in the EcoStart project is to develop the concept, to ensure a high standard of the authorized and auditing consultants and to recommend consultants to the companies. In this way strong neutrality is ensured. A close communication between the company and the consultant during the project is important to carry out the project successfully. Municipalities are not involved.

\section{EMS Light Nordic}

EMS Light Nordic doesn’t require certification or annual reporting. The system must mainly be considered as an internal follow-up system in order to improve the ecoefficiency. Thus there are no regular communication channels with the authorities.

\subsection{Good examples}

\section{Eco-Lighthouse}

Express Tekstil Service AS, Steen Arne Hansen:

"Eco-Lighthouse has made our whole organisation more aware of the importance of energy-efficiency, optimisation of transports and waste handling, which gives us better economy in addition to the reduction of our environmental impact. We have reduced our energy costs and waste costs. Separating different waste fractions has been of great importance.

Our working environment has been checked up, which hopefully will decrease the sickness rate in the long run.

We have noticed a positive response from our customers and suppliers. We are using the certificate in our marketing and hope that our environmental profile will give us more customers.

A weakness for our branch is that only few laundries are certified. More certified laundries would increase Eco-Lighthouse's knowledge of our branch and it would be easier to define relevant branch criteria. We think that Eco-Lighthouse has a great developmental potential and that many companies want to certify their business in the future. More and more big companies require that their suppliers have implemented an EMS.”

\section{Green Network}

Aarstiderne A/S, Svend Daverkosen: 
"Green Network has given us a good framework for the environmental work. It offers the persons working with environmental matters a professional tool. Our impression is that in addition to improved environmental performance our EMS also saves money, but it is difficult to measure.

In the future we hope that the EMS will be better implemented in other activities and that the goals are on a higher level than for the time being.”

\section{Environmental Diploma}

Stenungsundshem AB, Morgan Dahlborg:

"Environmental Diploma ensures that we continuously improve our environmental performance. The owners and the board of the company consider the environmental work as important and have accepted that it costs some money. The annual audit keeps up the environmental awareness in the whole organization.

Many of our contractors have chosen Environmental Diploma, because it is also suitable for micro companies. They benefit from it in purchase. We allow a higher price from those, which are certified.

Economic benefits of the EMS can be seen in our follow-up of consumptions of energy and water. There is also a clear marketing advantage, but it is difficult to measure.

In the future we will join a model including all three areas of sustainable development; environment, economy and social commitment. Our EMS will be included in that model.

The help we get from the environment administration in Göteborg is very valuable. The cost we pay is small compared to what we get in return from the annual audit.

In the future I hope the Environmental Diploma would include the whole concept of sustainable development, because the environmental work is closely related to economy and social commitment."

\section{EcoStart}

Participants in the Eco Start project are introduced in a recently published report, www.te-keskus.fi/Etelä-Savo/Ajankohtaista.

\section{EMS Light Nordic}

Colorant Chromatics Ab, Bo Sjöblom:

"EMS Light Nordic has given us a simple follow-up system for consumptions and costs of raw materials, chemicals and energy. In addition to the follow-up tables the system offers visual presentations of the eco-efficiency. 
So far we have identified the significant environmental aspects and defined targets and action plans for the most important aspects. EMS Light Nordic shows the correlation between a decrease in the environmental impact and cost savings, which makes the environmental work very interesting."

\section{Main results}

The five assessed systems have many features in common. All five models are less formal than ISO 14001 and EMAS. The most essential parts of an effective structural environmental work are covered by all systems. The systems are focusing on concrete environmental improvements, not on detailed documentation routines. The requirement on certification and regular re-certification motivates the companies to keep up the process regarding continuous improvement. In the case EMS light Nordic, that doesn't require certification, the company must have the motivation to continue the environmental work on its own initiative after the project period. It is extremely important that the results of the environmental work are visible and profitable.

A significant difference in relation to ISO 14001 and EMAS is also the role of the municipalities. The involvement of the municipalities is very strong regarding Environmental Diploma and Green Network, where no external consultants are used. The municipalities' own experts are acting advisors to the companies. This strengthens the dialogue between the municipalities and the companies. Regarding Eco-Lighthouse and EcoStart consultants are educated to assist the companies. For the EcoStart project consultants are also educated to carry out the certification audit, while Eco-Lighthouse uses municipal representatives for the certification process. Regarding EMS Light Nordic the environmental authorities choose the consultant.

Although all the models are much alike, there are some features that could be characterized as strengths for each system compared to the other assessed systems.

These features are listed below:

\section{Eco-Lighthouse}

- a numerous amount of users, well known in Norway

- own website www.miljofyrtarn.no

- the certificate is geographically neutral so that all municipalities can use it

- the action plan is included in the company's budget plan

- strengthens the co-operation between companies, municipalities and other interest groups

\section{Green Network}

- included in the national umbrella Key2Green

- own website www.greennetwork.dk

- the dialogue between local authorities and companies is central and a very strong element in the concept

- $\quad$ the flag gives visibility

\section{Environmental Diploma}

- included in the national umbrella Svensk Miljöbas

- own website www.miljodiplom.se 
- the strong local consolidation strengthens the co-operation between companies and the local municipality

- $\quad$ easy to work independently with the pedagogical model

\section{EcoStart}

- strong focus on cost-saving actions

- includes actions for slowing climate change

- the companies' time resources are observed

- low costs for companies

\section{EMS Light Nordic}

- own website www.ems-light.org

- the Excel-based follow-up system allows a continuous graphical follow-up of both consumptions and costs

- $\quad$ easy to visualize results from made actions

All systems have in common that they are clear and relatively simple. They are suitable especially for SMEs with limited resources but a genuine will to work systematically with environmental matters. With the EMS the eco-efficiency will increase and the company image will improve. 


\section{Conclusions}

Environmental requirements from customers and consumers are growing constantly. To meet these requirements the suppliers can implement an EMS according to either ISO 14001 or EMAS, which require a lot of resources regarding time and money but are well known, or an less formal EMS, which is less bureaucratic focusing on the concrete environmental work, but less known. For SMEs the less formal systems are popular because of their down-to-earth touch and lower costs. Anyhow, companies cannot fully benefit from the less formal EMS in their marketing, because the EMS alternatives are not known enough among customers. It's not easy for the customer to know what the different EMS alternatives present compared to each other.

Currently established less formal EMSs are known in regions where the municipalities are supporting the project. In Norway the ECO-Lighthouse foundation is working nationally. In Sweden and in Denmark national umbrellas have been established in order to collect less formal EMSs, which fulfil certain criteria, under the same roof. This helps the EMSs to become more known and to expand. Still the national umbrellas are not known outside the nation borders. The next step in the development of Nordic EMSs could be to develop a Nordic umbrella. This would give the Nordic EMSs credibility and make them known in all Nordic Countries.

SMEs expect clear measurable improvements and they should be cost-effective. In addition to the more eco-effective business the companies also expect that the EMS offers competitive advantage. For SMEs it is important that the implementation of the system can be carried out with relatively low costs and that the project is not too timeconsuming. The personnel at SMEs are mainly bound to day-to-day tasks and resources for development work are extremely small. Concrete results are a necessity to keep management and personnel motivated and to make the environmental work successful. Also the requirements on a regular re-certification is important to motivate the companies to go on with the environmental improvements after certification.

A benefit with all five assessed systems is that they are developed to suit all kinds of SMEs. The number of employees can vary from a few to a couple of hundred and the environmental impact varies depending on the business sector. Even a less formal EMS can seem to be too bureaucratic and too expensive to micro businesses if the EMS can't meet their specific needs.

The close co-operation between municipalities and companies strengthens the relation between the private sector and government officials. It is important that the companies fully understand that besides the authority role government officials also have a role as advisor to different actors in the society, among others SMEs. A less formal EMS supported by the municipality is a good example of a valuable cooperation where the municipality acts as advisor. 


\section{Sources}

$\underline{\text { www.eco-lighthouse.com }}$

www.miljofyrtarn.no

www.miljodiplom.se

www.miljo.goteborg.se

www.svenskmiljobas.se

www.greennetwork.dk

$\underline{\text { www.key2green.dk }}$

www.ems-light.org

Presentations from the workshop Nordic E-Coop for SMEs in Helsinki 12-13.3.2008

E-mail correspondence with representatives for the assessed systems

E-mail correspondence with companies using the assessed systems 
Comparison of criteria and tools for less formal EMSs within the frames of the project Nordic E-Coop for SMEs

27 June 2008

Ann-Christine Eriksson

Oy Eco Profile Ab 
Comparison of criteria and tools for less formal EMSs within the frames of the project Nordic E-Coop for SMEs

Contents

1. Introduction

2. The 4Steps methodology

$2.1 \quad$ Eco-Lighthouse

2.2 Environmental Diploma

2.3 Green Network/Key2Green

3. Conclusions

Sources

Appendix 1 


\section{Introduction}

This study is part of the project Nordic E-Coop for SMEs with purpose at developing the Nordic co-operation between existing less formal EMS initiatives for SMEs.

The aim of the study is to compare three less formal EMS frameworks with focus on similarities and differences regarding criteria and tools. The subjects of the study are:

\begin{tabular}{lll} 
EMS & Country & Representative \\
\hline Eco-lighthouse & Norway & $\begin{array}{l}\text { Eco-Lighthouse, Kristiansand, } \\
\text { Morten Leuch Elieson }\end{array}$ \\
$\begin{array}{l}\text { Environmental } \\
\text { Diploma }\end{array}$ & Sweden & $\begin{array}{l}\text { City of Göteborg, Göteborg, } \\
\text { Peer-Erik Carlsson }\end{array}$ \\
$\begin{array}{l}\text { Green Network/ } \\
\text { Key2Green }\end{array}$ & Denmark & $\begin{array}{l}\text { Green Network, Vejle, } \\
\text { Ole Dall }\end{array}$
\end{tabular}

\section{The 4Steps methodology}

The EMS initiatives are compared regarding similarities and differences in criteria and tools. The comparison is based on the 4Steps model from the presentation "Huey, Dewey and Louie" at the workshop Nordic E-Coop for SMEs 12-13 March 2008 in Helsinki. According to the 4Steps methodology, which is developed by Steen\&Strom, owner of several business centres in Norway, Sweden and Denmark, activities shall be performed and results achieved through four steps: Initiate, Plan, Act and Certify.

The main purpose of step 1, Initiate, is to establish contact between the company and involved consultants or advisors from the municipality and to sign a contract.

The main purpose of step 2, Plan, is to establish a project plan and to carry out an environmental review including assessment of the environmental aspects and to do action plans for the most important of the significant aspects.

The main purpose of step 3, Act, is to educate employees, implement the system and necessary routines in the organisation and execute the action plans.

The main purpose of step 4, Certify, is to carry out the certification occasion. 
In the following, each system's criteria and requirements are separately explained according to the 4Steps model. The work after certification is also clarified.

In Appendix 1 the systems are compared to each other step by step according to the 4Steps model. The appendix is made especially for companies to help them to compare the requirements of the three Nordic systems.

\section{$2.1 \quad$ Eco-Lighthouse}

\section{Step 1, Initiate}

The consultant, educated and approved by the Eco-Lighthouse office, and the company sign a contract and they inform the municipality about the project start. The consultant's role is to help the company to carry out an environmental analysis based on general criteria for all branches completed with branch criteria.

\section{Step 2, Plan}

When the contract between consultant and business has been signed, the process towards certification can start. The first action is to establish a working group, consisting of representatives from different levels and units in the organisation and the consultant, who acts both as project manager and secretary in the group. The employees shall be informed about the project.

The consultant helps the company to create an environmental analysis. First the working group has to evaluate all the topics included in the list of general criteria for all branches, and decide which ones are most important. The topics to be evaluated are:

- Internal control, Health, Environment and Safety

- Working environment

- Material purchasing and use

- Waste

- Energy

- Transportation

- Water pollution

- Air pollution/Noise (only relevant in some of the special branch criteria)

- Aesthetics

Eco-Lighthouse is based on an internal control system for health, environment and safety (HMS-system). If no functioning HMS-system is used, such a system must be established before the environmental analysis can be done.

In addition to the general criteria for all branches, specific branch criteria must also be fulfilled. There are 69 separate lists of criteria for specific branches. All criteria with "shall" and half of the criteria with "should" must be fulfilled. All legal requirements are marked with $\S$ and must be fulfilled.

It usually takes about six months to produce the environmental analysis including at minimum 2-3 meetings with the consultant. The consultant's role is to give ideas and 
knowledge about environmental issues, the employees are given the task of providing data and information to the meetings. A good teamwork guarantees good solutions.

Based on the environmental analysis an action plan shall be done. The working group has to decide which environmental aspects are most significant and to determine relevant actions.

When the environmental analysis is done, the consultant writes a consultant's report, where the start status, the process, actions that have been done and actions that will be done before certification are described. The consultant sends the report to the municipality that is responsible for the certification.

\section{Step 3, Act}

The environmental work and the internal communication shall be implemented in the organisation. The employees shall receive education at the project start, when the environmental analysis is ready and later during the ongoing environmental work. This is important in order to motivate the employees to take part in the environmental work.

Necessary procedures or routines must be established and documented in order to meet the criteria. The procedures can preferably be closely linked to the HMS-system.

Useful tools have been created in order to help the companies to establish new routines:

- Checklist for energy efficiency

- Guide for purchasing

- A simple HMS-scheme (health, environment and safety)

- Climate calculator

\section{Step 4, Certify}

The municipality is responsible for the certification. At the certification audit the auditor from the municipality is checking that the general criteria and the branch criteria are fulfilled. The auditor writes a certification report including possible deviations. There is a ready-made template on the website that shall be used for the certification report. When possible corrective actions are done, the company receives a certificate.

\section{After certification}

The certified company is responsible for continuing the environmental work after certification. A person in charge of environmental issues has to be appointed. This person is responsible for

- follow-up of the environmental work

- communication with Eco-Lighthouse

- informing and motivating employees

- informing customers

- creating annual environmental report for past year including action plan for current year and sending it to the Eco-Lighthouse office 
- initiating re-certification every third year

The first annual environmental report and action plan are made together with the consultant, but after that the company is responsible for making and sending the report to the Eco-Lighthouse office. Ready-made templates shall be used for the report. An electronic reporting system has been developed and will be in use in the near future.

\subsection{Environmental Diploma}

\section{Step 1, Initiate}

After the municipality has received an application from the company, an advisor from the municipality visits the company and informs about the working material and the requirements. The company receives access to the working material including guides, a checklist and examples on important documents. After the first meeting the company starts to go through the process independently. The municipality makes an offer to the business concerning the municipality's work in the project (audit, evaluation of the environmental documents). The company confirms the offer and returns a signed contract.

\section{Step 2, Plan}

The company works independently with the environmental investigation using the manual, which includes the essence of the work, the checklist. The checklist consists of

- Compliance with the legal requirements

- Obligatory issues

- Practical actions

All legal requirements must be fulfilled. In addition to the legal requirements there are nine obligatory issues that must be fulfilled and $75 \%$ of the practical actions must be done. All branches can use the standard checklist, but there are also special checklists for schools, manufacturing, hotels and restaurants. The standard checklist is created to suit all kinds of businesses and is therefore very large. The business can add own good solutions to the standard checklist and remove non-relevant requirements.

The nine obligatory issues are:

- Person in charge of environmental issues

- Environmental analysis including identification of environmental impact

- Environmental policy

- Action plan and targets

- Environmental training

- Inventory of chemicals

- Routines for purchase

- Register of waste amounts

- Regular environmental communication within the company 
The practical actions concern:

- Facilities

- Personnel

- Office

- Purchase

- Waste handling

- Transportation

- Chemicals

When the checklist is filled out, the environmental aspects have to be evaluated in order to identify the most significant aspects. Based on the significant aspects the environmental policy and the action plan shall be formulated.

\section{Step 3, Act}

Before the final audit can take place, the employees have to be educated. The business shall contact a consultant to arrange a half-day's education.

Necessary new routines and measures in order to fulfil the criteria shall be implemented in the organisation.

When necessary actions have been executed, the company shall send following documents to the municipality:

- Environmental analysis including description of the most significant environmental aspects

- Environmental policy

- Action plan including targets

- Record of environmental education

- List of chemicals (the auditor can also ask for safety data sheets)

- Routine for purchase

- Record of waste amounts

- Filled checklist

\section{Step 4, Certify}

After the documents are approved by the municipality's special experts date for final environmental audit can be decided. An auditor from the municipality is checking that everything in the checklist and other documents comply with the requirements and the reality. In case of deviations, corrective actions have to be made. When the compliance is considered as good, the company is awarded a diploma.

\section{After certification}

Re-certification has been required every year, but in the future the interval can be longer, up to three years, depending on the agreement between the company and the municipality. In addition to the documents required for the first certification the company has to deliver following new documents:

- Environmental declaration from the most important subcontractors and entrepreneurs 
- Written follow-up and environmental report including action plan for following year

After the municipality's specialists have checked the material, an audit in the company is carried out.

\subsection{Green Network/Key2Green}

\section{Step 1, Initiate}

The business meets a specialist from the municipality and they sign a contract on participating in the Green Network/Key2Green program.

\section{Step 2, Plan}

First of all a project plan shall be done by the management and/or the person in charge of environmental issues, if needed in collaboration with Green Network/municipality. The employees shall be informed, as well. The project plan shall include:

- The goal of the project

- The project organisation

- The schedule

- The resources allocated

- Employee information

- Supplementary training

The next step is to do the mapping for an environmental statement. The mapping process consists of three main areas with following content:

- Master data, products and use of resources

o Basic data about the business

o Requirements on sub-contractors

0 Product range and amounts

o Raw materials and ancillary materials

o Energy and water

o Transport

- External environment
o Air pollution
o Waste water
o Discharges to the ground
o Waste
o External noise, vibrations and odours
o Risks
o Operational interruptions
o Ground and groundwater pollution

- Occupational health and safety* (shall be considered if following conditions are relevant)

o Physical conditions

o Vibrations 

o Radiation
o Thermal strains
o Ergonomic conditions
o Psycho-social stress
o Chemical conditions
o Biological conditions
o Danger of accidents

*Demands on occupational health and safety are not included in this study except workplace evaluation, which is obligatory and a legal requirement.

Then an assessment of the environmental aspects and impact shall be done, in order to classify the aspects according to their significance. The choice of method is free but there has to be a description of the method.

Based on the assessment an environmental policy reflecting the company's intentions and principles in the environmental field shall be done.

\section{Step 3, Act}

For those environmental impacts, which require actions, an action plan including targets shall be created. Proposals for the action plan shall be assessed from a technical, environmental and economical point of view. The best proposals are included in the action plan.

Short procedures should be established for following issues:

- Mapping environmental impacts and workplace evaluations

- Environmental assessment

- Operating instructions for dealing with the most significant environmental impacts

- Environmental improvement projects

- Drawing up an environmental statement

The environmental statement is the essence of all environment related documents. It shall contain:

- Basic data about the business

- Key figures from the mapping

- Any changes in scope of the key figures

- Summary of own control measures compared to legal requirements

- Fulfilment of targets and action plan

- Environmental policy, targets and action plans

- Requirements on suppliers

- Description of methods of training employees

- Management report

\section{Step 4, Certify}


The environmental statement has to be submitted to the Green Network secretariat within three years from the start. Once the environmental statement corresponds to the requirements the company can be awarded a Green Network diploma and a Green Network flag.

\section{After certification}

The environmental statement has to be updated and approved by the municipality every second year.

\section{Conclusions}

The three compared EMSs are very much alike. Differences are mainly to be found in the way of working and in the tools, but the results and demands are almost the same.

The tools and working process for the environmental analysis are different in the three systems:

For Eco-Lighthouse users the general and the branch-specific checklists are the main tools in the environmental analysis. A consultant helps the companies to create the analysis.

Environmental Diploma criteria include a large detailed checklist. By counting the amount of "yes" and "no" answers the company easily gets a good picture of present environmental conditions. In addition to the checklist, the toolbox includes a large amount of guides, examples and explanations, which are of great importance, because the companies work independently with the material, without external expertise.

Green Network/Key2Green users follow the detailed guides in the manual, step by step. They also have support from the municipality during the project, when needed.

The next working process after the environmental analysis, including assessment of environmental aspects, action plan, communication and implementation of routines, are very similar.

A notable difference is the interval for environmental reporting and re-certification:

Eco-Lighthouse

Interval environ-

mental report, year

Interval re-

certification, year
1

3

\section{Environmental Diploma}

Green Network/ Key2Green
$1(-3)^{*}$

$1(-3)^{*}$
2

2

*will change from 1 to flexible, max. 3

Although there are differences in the working processes and in the tools, the demands are on the same level for all three systems. 


\section{Sources}

www.eco-lighthouse.com

www.miljofyrtarn.no

$\underline{\text { www.miljodiplom.se }}$

www.miljo.goteborg.se

www.greennetwork.dk

$\underline{\text { www.key2green.dk }}$

E-mail correspondence with representatives for the compared systems

Presentations from the workshop Nordic E-Coop for SMEs in Helsinki 12-13.3.2008

Presentations from the workshop Nordic E-Coop for SMEs in Göteborg 9-10.6.2008 


\section{Comparison of criteria}

\begin{tabular}{|c|c|c|}
\hline Eco-Lighthouse & Environmental Diploma & Green Network/Key2Green \\
\hline $\begin{array}{l}\text { Checklist } \\
100 \% \text { of "shall" demands and } 50 \% \\
\text { of "should" must be fulfilled }\end{array}$ & $\begin{array}{l}\text { Checklist } \\
\text { The legal requirements, all obligatory demands and } \\
75 \% \text { of the practical actions must be fulfilled }\end{array}$ & $\begin{array}{l}\text { Mapping } \\
\text { All items must be dealt with }\end{array}$ \\
\hline GENERAL CRITERIA & LEGAL REQUIREMENTS & $\begin{array}{l}\text { MASTER DATA, PRODUCTS AND USE } \\
\text { OF RESOURCES }\end{array}$ \\
\hline $\begin{array}{l}\text { The company shall have clearly defined goals, } \\
\text { working conditions included }\end{array}$ & We comply with the legislation & Basic data about the business \\
\hline $\begin{array}{l}\text { The company shall have an internal control } \\
\text { system to ensure the functioning of health, } \\
\text { environment and safety rules }\end{array}$ & OBLIGATORY DEMANDS & Manager in charge of the environmental work \\
\hline All environmental permitsshall be followed & $\begin{array}{l}\text { We have appointed at least one representative } \\
\text { responsible for the internal environmental work }\end{array}$ & Accounting period \\
\hline $\begin{array}{l}\text { Employees shall be informed of, and participate } \\
\text { actively in making the company more } \\
\text { environmental friendly and a better place to work }\end{array}$ & $\begin{array}{l}\text { We have identified and documented the most } \\
\text { significant impacts in an environmental } \\
\text { investigation by using the template }\end{array}$ & Information about any wastewater permits \\
\hline $\begin{array}{l}\text { The company shall select a representative to } \\
\text { be responsible for writing environmental reports } \\
\text { and developing and maintaining environmental } \\
\text { programs }\end{array}$ & We have formulated an environmental policy & $\begin{array}{l}\text { Information about evaluation of working } \\
\text { environment }\end{array}$ \\
\hline $\begin{array}{l}\text { An environmental status report for the previous } \\
\text { year including an action plan for current year } \\
\text { shall be made using the template }\end{array}$ & $\begin{array}{l}\text { We have done an action plan including } \\
\text { concrete targets for following year }\end{array}$ & $\begin{array}{l}\text { Information about significant resources and } \\
\text { environmental parameters including environmentally } \\
\text { harmful substances }\end{array}$ \\
\hline $\begin{array}{l}\text { The report shall be distributed to the } \\
\text { Eco-Lighthouse office }\end{array}$ & $\begin{array}{l}\text { Our employees have got environmental } \\
\text { education (min } 4 \text { hours) and new employees will } \\
\text { receive education within a year }\end{array}$ & $\begin{array}{l}\text { Information about the proportion of } \\
\text { subcontractors of whom environmental requirements } \\
\text { have been made }\end{array}$ \\
\hline WORKING ENVIRONMENT & $\begin{array}{l}\text { We have a list of all chemicals and safety } \\
\text { data sheets for all chemicals }\end{array}$ & $\begin{array}{l}\text { Information about what environmental } \\
\text { requirements have been imposed from the } \\
\text { subcontractors }\end{array}$ \\
\hline $\begin{array}{l}\text { The company shall have access to health and } \\
\text { safety services }\end{array}$ & $\begin{array}{l}\text { We have a procedure for purchase in order } \\
\text { to encourage environment friendly purchases }\end{array}$ & $\begin{array}{l}\text { The product range and amounts must be } \\
\text { stated }\end{array}$ \\
\hline
\end{tabular}




\begin{tabular}{|c|c|c|}
\hline $\begin{array}{l}\text { Workplaces shall have adequate ventilation } \\
\text { and the ventilation systemshall be routinely } \\
\text { cleaned and inspected }\end{array}$ & $\begin{array}{l}\text { We have a documented report regarding the } \\
\text { waste handling }\end{array}$ & $\begin{array}{l}\text { The amounts of raw material and ancillary material } \\
\text { shall be calculated }\end{array}$ \\
\hline $\begin{array}{l}\text { Development discussions with the employees } \\
\text { shall be arranged annually }\end{array}$ & $\begin{array}{l}\text { We regularly inform all employees about our } \\
\text { environmental work }\end{array}$ & $\begin{array}{l}\text { The consumption of electricity, heating } \\
\text { fossil fuels and water shall be calculated }\end{array}$ \\
\hline $\begin{array}{l}\text { Employee duties should be as varied as } \\
\text { possible }\end{array}$ & PRACTICAL ACTIONS & $\begin{array}{l}\text { Internal transport, transport of goods and service } \\
\text { trips must be mapped }\end{array}$ \\
\hline \multicolumn{3}{|l|}{ Ergonomic conditions should be satisfactory } \\
\hline & FACILITIES & EXTERNAL ENVIRONMENT \\
\hline $\begin{array}{l}\text { The company should organise/sponsor sports } \\
\text { or physical activities for its employees }\end{array}$ & $\begin{array}{l}\text { We have A-classified fluorescent lamps } \\
\text { alternatively HF fluorescent lamps }\end{array}$ & $\begin{array}{l}\text { The amounts of substances emitted to the } \\
\text { air must be stated }\end{array}$ \\
\hline Smoking legislation shall be followed & We have low energy lamps & $\begin{array}{l}\text { The amounts of substances in waste water } \\
\text { must be stated }\end{array}$ \\
\hline $\begin{array}{l}\text { Indoor areas shall be tidy and cleaning should } \\
\text { be done in the most environmental way }\end{array}$ & $\begin{array}{l}\text { We have detectors, which control the lighting in } \\
\text { facilities we seldom use, alternatively, signs "turn off } \\
\text { the light" }\end{array}$ & $\begin{array}{l}\text { Pollutants discharged into the ground } \\
\text { must be stated }\end{array}$ \\
\hline $\begin{array}{l}\text { Safety data sheets for chemicals shall be } \\
\text { available for all users }\end{array}$ & $\begin{array}{l}\text { We have timers for control of electrical } \\
\text { equipment }\end{array}$ & $\begin{array}{l}\text { Information about waste fractions and } \\
\text { amounts and treating method (recycled, incinerated, } \\
\text { sent to landfill or special treatment) }\end{array}$ \\
\hline \multicolumn{3}{|l|}{ MATERIAL PURCHASE AND USE } \\
\hline $\begin{array}{l}\text { A checklist for environmental purchasingshall } \\
\text { be used to ensure the environmental perspective } \\
\text { in purchasing }\end{array}$ & $\begin{array}{l}\text { We have made the property holder aware of our } \\
\text { wish to prioritize environmental aspects }\end{array}$ & $\begin{array}{l}\text { Description of stocks of flammable, toxic } \\
\text { and environmentally hazardous substances }\end{array}$ \\
\hline $\begin{array}{l}\text { The company shall ask their main suppliers for } \\
\text { environmental documentation concerning their } \\
\text { environmental work }\end{array}$ & We have standing order on Bra miljöval etc. & $\begin{array}{l}\text { Description of possible accidents or } \\
\text { interruptions and corrective and preventive actions }\end{array}$ \\
\hline $\begin{array}{l}\text { As far as possible the company shall use } \\
\text { products with eco-labellinc }\end{array}$ & $\begin{array}{l}\text { We have followed up our annual consumption of } \\
\text { water and energy }\end{array}$ & $\begin{array}{l}\text { Possible pollution of the ground must be } \\
\text { stated }\end{array}$ \\
\hline $\begin{array}{l}\text { If there is an obstacle to environmental } \\
\text { purchasing in the purchasing chain, } \\
\text { the company shall try to change the purchase } \\
\text { policy }\end{array}$ & We have time control on our ventilation & \\
\hline $\begin{array}{l}\text { In case of outsourcing, the new suppliersshall } \\
\text { be influenced to sertification }\end{array}$ & $\begin{array}{l}\text { Our heating system is based on renewable } \\
\text { sources }\end{array}$ & \\
\hline
\end{tabular}




\begin{tabular}{|c|c|c|}
\hline $\begin{array}{l}\text { Use of floor space, use of materials, flexibel } \\
\text { ventilation shall be considered in new buildings } \\
\text { and when remodellinc }\end{array}$ & We have water saving toilettes (at least $50 \%$ ) & \\
\hline $\begin{array}{l}\text { Companies that are using water in the } \\
\text { production shall have a meter installed }\end{array}$ & $\begin{array}{l}\text { We have only water saving taps in basins, } \\
\text { showers and kitchens }\end{array}$ & $\begin{array}{l}\text { Information about ways the motivate the } \\
\text { staff to participate in the environmental work }\end{array}$ \\
\hline $\begin{array}{l}\text { The company shall currently consider/carry } \\
\text { out steps to reduce water consumption }\end{array}$ & $\begin{array}{l}\text { We adjust our heating and cooling systems in order } \\
\text { to reduce the energy consumption }\end{array}$ & $\begin{array}{l}\text { Information about preventive actions to } \\
\text { ensure compliance with environmental } \\
\text { permits }\end{array}$ \\
\hline $\begin{array}{l}\text { When bying machines noise levelshall be one } \\
\text { of the criteria }\end{array}$ & $\begin{array}{l}\text { We have an energy plan for the facilities, } \\
\text { alternatively, the equipment }\end{array}$ & Information about complains \\
\hline ENERGY & PERSONNEL & \\
\hline $\begin{array}{l}\text { Energy consumption shall be registered and } \\
\text { periodically checked }\end{array}$ & $\begin{array}{l}\text { We buy organic/fair trade coffee or tea for } \\
\text { our employees }\end{array}$ & \\
\hline $\begin{array}{l}\text { An energy analysisshall be done by an energy } \\
\text { advisor if the consumption is }>200000 \mathrm{kWh} / \mathrm{a} \\
\text { (excluding transports)' }\end{array}$ & $\begin{array}{l}\text { We buy ecological food and beverages for } \\
\text { our employees and customers }\end{array}$ & \\
\hline $\begin{array}{l}\text { When the energy consumption is }<200000 \\
\text { kWh/a a special checklist should be used }\end{array}$ & $\begin{array}{l}\text { We go in for environment related hobby-activities for } \\
\text { the employees }\end{array}$ & \\
\hline $\begin{array}{l}\text { Energy sources with less impactshould be } \\
\text { prefered when the price is likewise or close to } \\
\text { likewise }\end{array}$ & $\begin{array}{l}\text { Our environmental representative has received } \\
\text { thorough environmental education }\end{array}$ & \\
\hline $\begin{array}{l}\text { Focus should be put on low energy use when } \\
\text { bying new equipment }\end{array}$ & $\begin{array}{l}\text { We inform our employees about the environmental } \\
\text { impact of our products }\end{array}$ & \\
\hline $\begin{array}{l}\text { Internal routinesshall provide low energy use } \\
\text { for heating, ventilation, lighting and production }\end{array}$ & OFFICE & \\
\hline TRANSPORTATION & We only use eco-labelled office paper & \\
\hline $\begin{array}{l}\text { Employees shall be encouraged to bike, walk, } \\
\text { carpool or use public transportatior }\end{array}$ & We use eco-labelled envelopes & \\
\hline $\begin{array}{l}\text { Use of telephone and video conferencingshall } \\
\text { be considered }\end{array}$ & Our toner cassettes are Swan-marked & \\
\hline $\begin{array}{l}\text { Downtown companies shall not have more } \\
\text { parking places than necessary }\end{array}$ & $\begin{array}{l}\text { Our office equipment is eco-labelled } \\
\text { (at least } 50 \% \text { ) }\end{array}$ & \\
\hline $\begin{array}{l}\text { Transportation routes shall be co-ordinated to } \\
\text { eliminate unnecessary kilometres and vehicles } \\
\text { with less impact shall be chosen }\end{array}$ & $\begin{array}{l}\text { The energy saving function is activated in our } \\
\text { office equipment }\end{array}$ & \\
\hline $\begin{array}{l}\text { Regularly check-up and serviceshall be } \\
\text { carried out }\end{array}$ & $\begin{array}{l}\text { We have adjusted our equipment to print/copy on } \\
\text { both sides, alternatively, we have instructions how to } \\
\text { do it }\end{array}$ & \\
\hline
\end{tabular}




\begin{tabular}{|c|c|c|}
\hline $\begin{array}{l}\text { The company shall have statistics for each } \\
\text { vehicle's fuel consumption and take measures to } \\
\text { reduce these }\end{array}$ & $\begin{array}{l}\text { We have summarized the annual consumption } \\
\text { of paper }\end{array}$ & \\
\hline No engine idling! & We buy eco-labelled toilette and kitchen paper & \\
\hline Engine warmers ought to be installed & PRODUCTS AND SERVICES & \\
\hline Vehicles shall not use studded tires & $\begin{array}{l}\text { We serve our customers with environmental } \\
\text { information about our products }\end{array}$ & \\
\hline $\begin{array}{l}\text { The use of alternative energy driven vehicles } \\
\text { shall constantly be considerec }\end{array}$ & $\begin{array}{l}\text { We can show examples of our products' } \\
\text { environmental performance }\end{array}$ & \\
\hline WASTE & $\begin{array}{l}\text { We will use the Environmental Diploma in our } \\
\text { marketing }\end{array}$ & \\
\hline $\begin{array}{l}\text { The company shall implement a minimum of } \\
\text { three waste reduction actions }\end{array}$ & $\begin{array}{l}\text { Our printed matter is printed in Swan-labelled } \\
\text { printing houses }\end{array}$ & \\
\hline $\begin{array}{l}\text { The company and its suppliersshall not } \\
\text { over-pack goods. Packaging shall be re-usable } \\
\text { or at least recyclable. }\end{array}$ & WASTE AND RECYCLING & \\
\hline $\begin{array}{l}\text { Use of disposable products shall be kept } \\
\text { at minimum }\end{array}$ & We can show that we & \\
\hline $\begin{array}{l}\text { Receival of unadressed advertisement and } \\
\text { brochures shall be limited }\end{array}$ & - reuse cardboard boxes, wrapping, office paper & \\
\hline About $70 \%$ of waste shall be recycled & $\begin{array}{l}\text { - reuse furniture/inventories or give them to second } \\
\text { hand businesses }\end{array}$ & \\
\hline $\begin{array}{l}\text { The company's environmental representative } \\
\text { shall routinely check the waste management } \\
\text { including a thorough control twice a yea }\end{array}$ & We avoid disposable materials in following way: & \\
\hline $\begin{array}{l}\text { The company shall use all local systems for } \\
\text { recycling }\end{array}$ & We use return-wrapping or re-fill when possible & \\
\hline $\begin{array}{l}\text { Hazardous waste shall be properly stored and } \\
\text { disposed of }\end{array}$ & We don't use disposable paper or plastic service & \\
\hline $\begin{array}{l}\text { A list of waste management procedures shall } \\
\text { be available to all employees }\end{array}$ & $\begin{array}{l}\text { We always use big packages of milk, butter, } \\
\text { sugar etc. }\end{array}$ & \\
\hline WATER POLLUTION & $\begin{array}{l}\text { We have garbage bags made of recycled } \\
\text { paper/plastic or biodegradable material }\end{array}$ & \\
\hline $\begin{array}{l}\text { Vehicles shall be cleaned and degreased using } \\
\text { eco-detergents }\end{array}$ & $\begin{array}{l}\text { We separate waste more effectively than the } \\
\text { legislation requires }\end{array}$ & \\
\hline
\end{tabular}




\begin{tabular}{|c|c|c|}
\hline $\begin{array}{l}\text { Facilities where vehicles are washedshall have } \\
\text { approved drainage systems with oil and sand } \\
\text { filters and instructions for usage of these filters }\end{array}$ & TRANSPORTATION & \\
\hline AIR POLLUTION/NOISE & $\begin{array}{l}\text { We have written travel rules where environmental } \\
\text { aspects are prioritized }\end{array}$ & \\
\hline $\begin{array}{l}\text { Only relevant in some of the specific branch } \\
\text { criteria }\end{array}$ & $\begin{array}{l}\text { Personnel using car in work have been } \\
\text { educated in eco-driving }\end{array}$ & \\
\hline \multirow{2}{*}{\multicolumn{3}{|c|}{$\begin{array}{l}\text { When we rent cars, the fuel consumption has to } \\
\text { be below Gröna Bilisters requirements }\end{array}$}} \\
\hline & & \\
\hline \multirow[t]{15}{*}{$\begin{array}{l}\text { The company shall maintain its physical plant } \\
\text { and property }\end{array}$} & $\begin{array}{l}\text { We have tickets for use of public transports } \\
\text { in business travelling }\end{array}$ & \\
\hline & $\begin{array}{l}\text { The personnel have possibilty to use bicycles } \\
\text { in the work }\end{array}$ & \\
\hline & $\begin{array}{l}\text { We try to use the company's cars collectively or } \\
\text { we are connected to a car pool }\end{array}$ & \\
\hline & $\begin{array}{l}\text { We have cars included in the list of } \\
\text { best eco-cars }\end{array}$ & \\
\hline & $\begin{array}{l}\text { We have vihicles using alternative fuel or vihicles } \\
\text { which are classified as eco-vehicle }\end{array}$ & \\
\hline & $\begin{array}{l}\text { In wintertime our vehicles are in a garage or } \\
\text { connected to time-controlled motor heater }\end{array}$ & \\
\hline & $\begin{array}{l}\text { Our vehicles are washed in a hall equipped with } \\
\text { more cleaning equipment than only oil separator }\end{array}$ & \\
\hline & Our cars have eco-tires & \\
\hline & Our cars don't have studded tyres in wintertime & \\
\hline & $\begin{array}{l}\text { We have summarized our annual fuel } \\
\text { consumption in transportation }\end{array}$ & \\
\hline & $\begin{array}{l}\text { We have loading and unloading systems that } \\
\text { minimize energy loss }\end{array}$ & \\
\hline & $\begin{array}{l}\text { We have working vehicles, that fulfil the } \\
\text { requirements of Miljöklass } 2005 \text {, with low energy } \\
\text { demand compared to the size }\end{array}$ & \\
\hline & $\begin{array}{l}\text { We have made an investigation concerning the } \\
\text { employees' work trips }\end{array}$ & \\
\hline & $\begin{array}{l}\text { As a result we have made actions to reduce } \\
\text { work trips by car }\end{array}$ & \\
\hline & $\begin{array}{l}\text { We offer our employees cheaper public transit } \\
\text { as a salary profit }\end{array}$ & \\
\hline
\end{tabular}




\begin{tabular}{|c|c|c|}
\hline & $\begin{array}{l}\text { We encourage the employees to walk or bike } \\
\text { to work }\end{array}$ & \\
\hline & CHEMICALS & \\
\hline & $\begin{array}{l}\text { Chemical-free cleaning methods are used, } \\
\text { if possible }\end{array}$ & \\
\hline & Only eco-labelled agents are used in cleaning & \\
\hline & We use eco-labelled colorants & \\
\hline & $\begin{array}{l}\text { We use environmental friendly agents, fats and } \\
\text { oils in our vehicles }\end{array}$ & \\
\hline & $\begin{array}{l}\text { We use environmental friendly fuels in our } \\
\text { working equipment }\end{array}$ & \\
\hline & $\begin{array}{l}\text { We don't use chemical pesticides on the } \\
\text { outside area }\end{array}$ & \\
\hline & We use batteries that can be charged up & \\
\hline & $\begin{array}{l}\text { We have summarized our annual consumption } \\
\text { of fuel for machines and working equipment }\end{array}$ & \\
\hline & $\begin{array}{l}\text { We have noticed our chemicals' risk phrases } \\
\text { and they are included in the chemical list }\end{array}$ & \\
\hline $\begin{array}{l}\text { In addition to these general criteria there are } \\
\text { specific criteria for } 69 \text { specific branches! }\end{array}$ & $\begin{array}{l}\text { In addition to these criteria, the company can add } \\
\text { own good solutions to the list or remove non- } \\
\text { relevant criteria } \\
\text { There are also specific criteria for schools, } \\
\text { manufacturing, hotels and restaurants } \\
\end{array}$ & $\begin{array}{l}\text { Occupational health and safety can be } \\
\text { included, if wished }\end{array}$ \\
\hline
\end{tabular}

Assessment of the environmental aspects in order to find the significant aspects

\section{Action plans and targets}

Implementing routines

Environmental report/statement 


\section{Guide to companies}

\begin{tabular}{|c|c|c|}
\hline \multicolumn{3}{|c|}{ Step 1, Initiate } \\
\hline Eco-Lighthouse & Environmental Diploma & Green Network/Key2Green \\
\hline $\begin{array}{l}\text { Take contact to a consultant, educated and } \\
\text { approved by the Eco-Lighthouse office, or to the } \\
\text { Eco-Lighthouse office, which can nominate a } \\
\text { consultant }\end{array}$ & Make an application to the municipality & $\begin{array}{l}\text { Arrange a meeting with an environmental advisor from } \\
\text { the municipality }\end{array}$ \\
\hline $\begin{array}{l}\text { Sign a contract with the consultant. The consultant } \\
\text { will help the company to carry out an } \\
\text { environmental analysis }\end{array}$ & $\begin{array}{l}\text { An environmental advisor from the municipality makes } \\
\text { a visit and informs about the requirements and } \\
\text { working material in order to give the business capability } \\
\text { to carry out the project independently without external } \\
\text { help }\end{array}$ & $\begin{array}{l}\text { Sign a contract with the environmental advisor. The } \\
\text { advisor will help the business to produce an } \\
\text { environmental statement }\end{array}$ \\
\hline Inform the municipality about the project start & $\begin{array}{l}\text { The municipality makes an offer regarding evaluation of } \\
\text { the environmental documents and the certification audit } \\
\text { Confirm the offer and start the project }\end{array}$ & \\
\hline
\end{tabular}




\section{Guide to companies}

\begin{tabular}{|c|c|c|}
\hline \multicolumn{3}{|c|}{ Step 2, Plan } \\
\hline Eco-Lighthouse & Environmental Diploma & Green Network/Key2Green \\
\hline $\begin{array}{l}\text { Establish a working group, consisting of } \\
\text { representatives from employees and management } \\
\text { and the consultant (project manager and secretary) }\end{array}$ & $\begin{array}{l}\text { Examine the working material and start working } \\
\text { with the guide and the checklist }\end{array}$ & $\begin{array}{l}\text { Make a project plan including the goal of the project, } \\
\text { project organisation, schedule, necessary resources, } \\
\text { information to the employees and supplementary training }\end{array}$ \\
\hline Inform the employees about the project & $\begin{array}{l}\text { The checklist consists of 1) compliance with legal } \\
\text { requirements, 2) obligatory issues and 3) practical actions }\end{array}$ & $\begin{array}{l}\text { Use the manual and do the mapping for the } \\
\text { environmental statement. The mapping consists of three } \\
\text { main areas: 1) Master data, 2) external environment and } \\
\text { 3) occupational health and safety (if relevant) }\end{array}$ \\
\hline $\begin{array}{l}\text { Evaluate the topics in the list of general branch } \\
\text { criteria: } \\
\text { - Internal control of health, environmnet and safety } \\
\text { - Working environment } \\
\text { - Material purchasing and use } \\
\text { - Waste } \\
\text { - Energy } \\
\text { - Transportation } \\
\text { - Water pollution } \\
\text { - Air pollution/Noise (only relevant in some of the } \\
\text { special branch criteria) } \\
\text { - Aestethics }\end{array}$ & $\begin{array}{l}\text { There are nine obligatory issues: } \\
\text { - Person in charge of the environmental work } \\
\text { - Environmental analysis } \\
\text { - Environmental policy } \\
\text { - Action plan and targets } \\
\text { - Environmental training } \\
\text { - Inventory of chemicals } \\
\text { - Routines for purchase } \\
\text { - Register of waste amounts } \\
\text { - Regular internal environmental communication }\end{array}$ & $\begin{array}{l}\text { Master data consist of basic data about the business, } \\
\text { requirements on sub-contractors, product range and } \\
\text { amounts, raw materials and ancillary, energy and water, } \\
\text { transport } \\
\text { External environment consists of } \\
\text { - air pollution } \\
\text { - waste water } \\
\text { - discharges to the ground } \\
\text { - waste } \\
\text { - external noise, vibrations and odours } \\
\text { - risks } \\
\text { - operational interruptions } \\
\text { - ground and groundwater pollution }\end{array}$ \\
\hline Evaluate the topics in the specific branch criteria & $\begin{array}{l}\text { Use the standard checklist or, if relevant, the specific } \\
\text { checklists for schools, manufacturing, hotels and } \\
\text { restaurants }\end{array}$ & $\begin{array}{l}\text { Note! The section "occupational health and safety" } \\
\text { is not included in this study }\end{array}$ \\
\hline $\begin{array}{l}\text { All "shall" criteria, half of "should" criteria must } \\
\text { be fulfilled, legal requirements (marked with §) } \\
\text { must be fulfilled }\end{array}$ & $\begin{array}{l}\text { All obligatory issues must be fulfilled and } 75 \% \text { of } \\
\text { the practical actions must be done }\end{array}$ & \\
\hline $\begin{array}{l}\text { Decide which environmental aspects are most } \\
\text { significant and create an action plan }\end{array}$ & $\begin{array}{l}\text { Make an environmental investigation in order to identify } \\
\text { the significant aspects }\end{array}$ & $\begin{array}{l}\text { Classify the environmental aspects by free choice of } \\
\text { method, but describe the method }\end{array}$ \\
\hline $\begin{array}{l}\text { The consultant writes a project report including a } \\
\text { description of made actions and actions to be } \\
\text { made before certification }\end{array}$ & $\begin{array}{l}\text { Based on the significant environmental aspects, } \\
\text { formulate an environmental policy }\end{array}$ & $\begin{array}{l}\text { Based on the classification, formulate an environmental } \\
\text { policy }\end{array}$ \\
\hline $\begin{array}{l}\text { The consultant sends the report to the } \\
\text { municipality }\end{array}$ & $\begin{array}{l}\text { Based on the significant environmental aspects, } \\
\text { create an action plan }\end{array}$ & $\begin{array}{l}\text { Then, define targets and create an action } \\
\text { plan }\end{array}$ \\
\hline
\end{tabular}

Oy Eco Profile Ab 


\section{Guide to companies}

\begin{tabular}{|c|c|c|}
\hline \multicolumn{3}{|c|}{ Step 3, Act } \\
\hline Eco-Lighthouse & Environmental Diploma & Green Network/Key2Green \\
\hline Arrange environmental education of the staff & 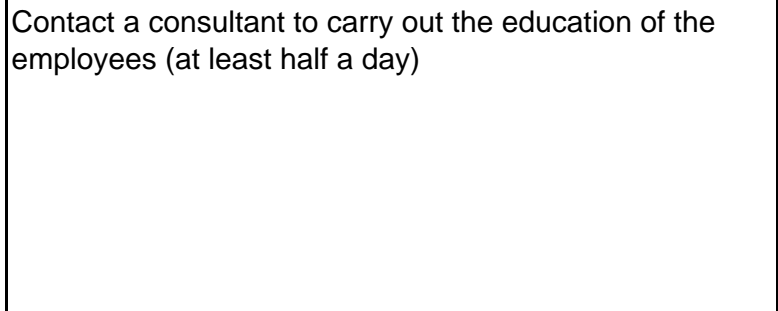 & $\begin{array}{l}\text { When the action plan is done, make procedures for: } \\
\text { - Mapping environmental impacts and workplace } \\
\text { evaluations } \\
\text { - Environmental assessment } \\
\text { - Operating instructions for dealing with the most } \\
\text { significant environmental impacts } \\
\text { - Environmental improvement projects } \\
\text { - Drawing up an environmental statement }\end{array}$ \\
\hline $\begin{array}{l}\text { Based on the significant environmental aspects } \\
\text { and the action plan, establish necessary } \\
\text { procedures and link them } \\
\text { to the HMS-system, if possible }\end{array}$ & $\begin{array}{l}\text { Use the guides and study the examples in the manual } \\
\text { in order to fulfil all requirements }\end{array}$ & \\
\hline $\begin{array}{l}\text { On the website you can find useful tools: } \\
\text { - Checklist for energy efficiency } \\
\text { - Guide for purchasing } \\
\text { - A simple HMS-scheme } \\
\text { - Climate calculator }\end{array}$ & $\begin{array}{l}\text { Create necessary procedures and implement them in the } \\
\text { organisation }\end{array}$ & Implement the procedures in the organisation \\
\hline $\begin{array}{l}\text { When the system is implemented successfully, } \\
\text { create an environmental report by using the } \\
\text { template on the website }\end{array}$ & $\begin{array}{l}\text { Collect following documents: } \\
\text { - Environmental analysis } \\
\text { - Environmental policy } \\
\text { - Action plan including targets } \\
\text { - Record of environmental education } \\
\text { - List of chemicals } \\
\text { - Routine for purchase } \\
\text { - Record of waste amounts } \\
\text { - Filled checklist }\end{array}$ & $\begin{array}{l}\text { Make an environmental statement including: } \\
\text { - Basic data about the business } \\
\text { - Key figures from the mapping } \\
\text { - Any changes in scope of the key figures } \\
\text { - Summary of measures compared to legal requirements } \\
\text { - Fulfilment of targets and action plan } \\
\text { - Environmental policy, targets and action plan } \\
\text { - Requirements on suppliers } \\
\text { - Training of employees } \\
\text { - Management report }\end{array}$ \\
\hline $\begin{array}{l}\text { Send the report to the Eco-Lighthouse office } \\
\text { (an electronic reporting system is under } \\
\text { development and can in the near future be used) }\end{array}$ & Send the documents to the municipality & $\begin{array}{l}\text { Send the environmental statement to the Green } \\
\text { Network secretariat and to the municipality }\end{array}$ \\
\hline
\end{tabular}




\section{Guide to companies}

\begin{tabular}{|l|l|l|}
\hline \multicolumn{2}{|c|}{ Step 4, Certify } \\
\hline \multicolumn{1}{|c|}{ Eco-Lighthouse } & \multicolumn{1}{|c|}{ Environmental Diploma } & \multicolumn{1}{|c|}{ Green Network/Key2Green } \\
\hline $\begin{array}{l}\text { Decide a date for certification audit with the } \\
\text { municipality }\end{array}$ & $\begin{array}{l}\text { An auditor from the municipality visits the company } \\
\text { and checks that the checklist and the documentation } \\
\text { fulfil the requirements and correspond to reality }\end{array}$ & $\begin{array}{l}\text { The municipality's experts evaluate the environmental } \\
\text { statement }\end{array}$ \\
$\begin{array}{l}\text { An auditor from the municipality comes for a visit } \\
\text { and checks that the general criteria and the } \\
\text { branch criteria are fulfilled }\end{array}$ & $\begin{array}{l}\text { If the auditor considers the compliance as good, the } \\
\text { company receives a diploma. Otherwise corrective } \\
\text { actions have to be made before the diploma is awarded. }\end{array}$ & $\begin{array}{l}\text { If the environmental statement fulfils the requirements } \\
\text { the company can be awarded a Green Network diploma } \\
\text { and a flag }\end{array}$ \\
$\begin{array}{l}\text { The auditor writes a certification report on a } \\
\text { template from the website, and, when possible } \\
\text { deviations are corrected, the company receives a } \\
\text { certificate }\end{array}$ & & \\
\hline
\end{tabular}




\section{Guide to companies}

\begin{tabular}{|c|c|c|}
\hline \multicolumn{3}{|c|}{ After certification } \\
\hline Eco-Lighthouse & Environmental Diploma & Green Network/Key2Green \\
\hline $\begin{array}{l}\text { A person in charge for the environmental work } \\
\text { shall be appointed, who is responsible of, among } \\
\text { other things } \\
\text { - the annual report + action plan for current year } \\
\text { - initiating re-certification } \\
\text { Re-certification shall be arranged every third year }\end{array}$ & $\begin{array}{l}\text { Send the same documents as required for the first } \\
\text { certification to the municipality, completed with } \\
\text { - Environmental declaration from the most important } \\
\text { subcontractors and entrepreneurs } \\
\text { - Follow-up report and environmental report + action plan } \\
\text { to the municipality } \\
\text { Re-certification shall be arranged at least every third year } \\
\text { (until now every year) depending on the agreement } \\
\text { between the company and the municipality }\end{array}$ & $\begin{array}{l}\text { Send an updated environmental statement to the } \\
\text { municipality every second year }\end{array}$ \\
\hline
\end{tabular}

